Supplement of Atmos. Chem. Phys., 21, 13333-13351, 2021

https://doi.org/10.5194/acp-21-13333-2021-supplement

(C) Author(s) 2021. CC BY 4.0 License.

(c) (i)

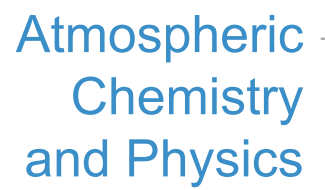

Supplement of

\title{
Role of Criegee intermediates in the formation of sulfuric acid at a Mediterranean (Cape Corsica) site under influence of biogenic emissions
}

\author{
Alexandre Kukui et al. \\ Correspondence to: Alexandre Kukui (alexandre.kukui@cnrs-orleans.fr)
}

The copyright of individual parts of the supplement might differ from the article licence. 


\section{Table of content}

S1 Previous studies

Table S1. Previous results on the $\mathrm{H}_{2} \mathrm{SO}_{4}$ budget

S2 Experimental setup

Figure S1. Schema of chemical conversion and ion molecular reactors

S3 Calibration of $\mathrm{OH}$ and $\mathrm{H}_{2} \mathrm{SO}_{4}$

S3.1 Calibration setup

Figure S2. Schema of the calibration setup

S3.2 Estimation of $\mathrm{OH}$ and $\mathrm{H}_{2} \mathrm{SO}_{4}$ concentrations produced by calibration setup

S3.3 Mass peaks intensities and $\mathrm{OH}, \mathrm{H}_{2} \mathrm{SO}_{4}$ concentrations

S3.4 Calibration example

$\mathrm{S} 3.4 .1 \mathrm{OH}$ and $\mathrm{H}_{2} \mathrm{SO}_{4}$ wall loss rates

Figure S3. Example of wall loss decay rate measurements

S3.4.2 Determination of $C_{\mathrm{N}_{2} \mathrm{O}}$ from $\mathrm{N}_{2} \mathrm{O}$ photolysis

Figure S4. Determination of the calibration coefficient $C_{\mathrm{N}_{2} \mathrm{O}}$

S3.4.3 Calibration of $\mathrm{OH}$ and $\mathrm{H}_{2} \mathrm{SO}_{4}$

Figure S5. Example of "fast" field calibration of $\mathrm{OH}$ and $\mathrm{H}_{2} \mathrm{SO}_{4}$

Figure S6. Comparison of measured $I^{\mathrm{OH}}$ and $I^{\mathrm{H} 2 \mathrm{SO} 4}$ with calculated $[\mathrm{OH}]$ and $\left[\mathrm{H}_{2} \mathrm{SO}_{4}\right]$

Figure S7. Example of $\mathrm{OH}$ calibration coefficient determination

Figure S8. Example of relative $\mathrm{OH}$ and $\mathrm{H}_{2} \mathrm{SO}_{4}$ sensitivity calibration

S3.5 Photochemical coefficients and uncertainty estimation

Table S2. Photochemical coefficients used for the calculation of $\mathrm{OH}$ and $\mathrm{H}_{2} \mathrm{SO}_{4}$

Table S3. Estimation of uncertainties

S4 Estimation of $\mathrm{H}_{2} \mathrm{SO}_{4}$ production in reactions of SCIs with $\mathrm{SO}_{2}$

Figure S9. Median diel concentration profiles of observed unsaturated VOCs

Table S4. Measured VOCs, measured techniques, median values, SCIs yields

Table S5. Rate coefficients for SCIs derived from observed unsaturated VOCs

Figure S10. Calculated mean diel concentration profiles of SCIs and $\mathrm{H}_{2} \mathrm{SO}_{4}{ }^{\mathrm{SCI}}$

S5 Validity of $\mathrm{H}_{2} \mathrm{SO}_{4}$ steady state approximation

Figure S11. Wind direction probability and wind speed at the Ersa site

Figure S12. Air mass presence time over the land and $\mathrm{H}_{2} \mathrm{SO}_{4}$ lifetime

S6 Importance of nucleation as a loss pathway of $\mathrm{H} 2 \mathrm{SO} 4$

Figure S13. Example of new particles formation event (NPF)

S7 SCIs interference with $\mathrm{OH}$ and $\mathrm{H} 2 \mathrm{SO} 4$ measurements

Figure S14 $\alpha$-pinene ozonolysis chamber study: dependence of background level on the SCI production rate

\section{References}




\section{S1 Previous studies}

Table S1. Previous results on the $\mathrm{H}_{2} \mathrm{SO}_{4}$ budget based on the studies including $\mathrm{OH}, \mathrm{H}_{2} \mathrm{SO}_{4}, \mathrm{SO}_{2}$ and particles measurements

\begin{tabular}{|c|c|c|c|c|c|c|c|}
\hline Air type & Location & $\mathrm{SO}_{2}, \mathrm{ppb}$ & $\begin{array}{l}\text { Condensation } \\
\text { sink (CS), s }{ }^{-1}\end{array}$ & $\begin{array}{l}\text { Used } k_{\mathrm{OH}+\mathrm{SO}_{2}} \\
\mathrm{~cm}^{3} \mathrm{mlk}^{-1} \mathrm{~s}^{-1} \\
(298 \mathrm{~K}, 1 \text { Atm) }\end{array}$ & $\begin{array}{c}\text { Ratio of } \\
{\left[\mathrm{H}_{2} \mathrm{SO}_{4}\right]} \\
/[\mathrm{OH}]\end{array}$ & $\begin{array}{l}\text { Ratio of } \mathrm{H}_{2} \mathrm{SO}_{4} \\
\text { production in } \\
\mathrm{OH}+\mathrm{SO}_{2} / \text { Loss } \\
\text { (if uptake = 1) }\end{array}$ & Ref \\
\hline $\begin{array}{l}\text { Remote } \\
\text { continental } \\
3000 \text { m a.s.l. }\end{array}$ & $\begin{array}{l}\text { Idaho Hill, Rocky } \\
\text { Mountains, Colorado, } \\
\text { TOHPE, } \\
\text { September } 1993\end{array}$ & $\approx 0.5^{\mathrm{a})}$ & $6 \times 10^{-3}$ b) & $8.5 \times 10^{-13}$ & $1-2^{a)}$ & $\approx 1$ & $\begin{array}{l}\text { (Weber et al., } \\
\text { 1997) }\end{array}$ \\
\hline $\begin{array}{l}\text { Remote marine, } \\
3400 \text { m a.s.l. }\end{array}$ & $\begin{array}{l}\text { Mauna Loa Obs., Hawaii } \\
\text { July, } 1992\end{array}$ & $\approx 0.5^{\text {a) }}$ & $10^{-3}-10^{-2}$ & $8.5 \times 10^{-13}$ & $\approx 1^{\mathrm{a})}$ & 1 & $\begin{array}{l}\text { (Weber et al., } \\
\text { 1997) }\end{array}$ \\
\hline $\begin{array}{l}\text { Remote marine, } \\
\text { polar }\end{array}$ & $\begin{array}{l}\text { Anvers Island, } \\
\text { western Antarctica, } \\
\text { SCATE, Jan.-Feb., } 1994\end{array}$ & $0.01-0.02$ & $10^{-4}-10^{-3}$ & $8.5 \times 10^{-13}$ & $8.7^{c)}$ & $\approx 0.1$ & $\begin{array}{l}\text { (Jefferson et } \\
\text { al., 1998) }\end{array}$ \\
\hline \multirow{4}{*}{$\begin{array}{l}\text { Forested rural } \\
\text { continental } \\
\text { mountain site }\end{array}$} & $\begin{array}{l}\text { Fritz Peak Obs., } \\
\text { Colorado, } \\
\text { June-August, } 1991\end{array}$ & $0.2-1^{\text {a) }}$ & $\approx 5 \times 10^{-3}$ a) & $8.5 \times 10^{-13}$ & $\approx 1^{\text {a) }}$ & $0.5-1$ & $\begin{array}{l}\text { (Eisele and } \\
\text { Tanner, 1993) }\end{array}$ \\
\hline & $\begin{array}{l}\text { Hohenpeissenberg, } \\
\text { southern Germany } \\
\text { April, } 1998\end{array}$ & $\approx 0.3^{\text {a) }}$ & - & $8.5 \times 10^{-13}$ & $\approx 1.5^{\text {a) }}$ & $\begin{array}{c}\approx 1 \\
>1 \text { e) }\end{array}$ & $\begin{array}{l}\text { (Birmili et al., } \\
2000)\end{array}$ \\
\hline & $\begin{array}{l}\text { Hohenpeissenberg, } \\
\text { southern Germany } \\
\text { HAFEX } 2000 \\
\text { April and June, } 2000\end{array}$ & $\approx 0.3^{\text {a) }}$ & $\approx 10^{-2}$ a) & $8.06 \times 10^{-13}$ & $\approx 1^{\text {a) }}$ & $\begin{array}{l}\approx 1 \text { day } \\
<0.5 \text { night }\end{array}$ & $\begin{array}{l}\text { (Boy et al., } \\
\text { 2013) }\end{array}$ \\
\hline & $\begin{array}{l}\text { Hohenpeissenberg, } \\
\text { southern Germany } \\
\text { HOPE } 2012 \\
11 / 07-19 / 08,2012\end{array}$ & $0.09^{c)}$ & $\left.7 \times 10^{-3} \mathrm{c}\right)$ & $1.3 \times 10^{-12}$ & $0.5^{c)}$ & 1.1 & $\begin{array}{l}\text { (Novelli et al., } \\
\text { 2017) }\end{array}$ \\
\hline \multirow{3}{*}{ Remote Coastal } & $\begin{array}{l}\text { Mace Head, Ireland } \\
\text { PARFORCE } \\
\text { June, } 1999\end{array}$ & $0.1-1^{\text {a) }}$ & $5 \times 10^{-3}-10^{-2}$ a) & $8.5 \times 10^{-13}$ & $\approx 5^{\text {a) }}$ & $<0.03$ & $\begin{array}{l}\text { (Berresheim } \\
\text { et al., 2002) }\end{array}$ \\
\hline & $\begin{array}{l}\text { Mace Head, Ireland } \\
2010-2011\end{array}$ & $\approx 0.2^{\text {a) }}$ & $\approx 3 \times 10^{-3}$ a) & $9 \times 10^{-13}$ & $7.1^{c)}$ & $\approx 0.2$ & $\begin{array}{l}\text { (Berresheim } \\
\text { et al., 2014) }\end{array}$ \\
\hline & $\begin{array}{l}\text { Finokalia, northern } \\
\text { coast of Crete (Eastern } \\
\text { Mediterranean) } \\
\text { MINOS, August, } 2001\end{array}$ & $\approx 1^{\text {a) }}$ & $\approx 10^{-2}$ a) & $8.5 \times 10^{-13}$ & $1-5^{\text {a) }}$ & $\approx 0.5$ & $\begin{array}{l}\text { (Bardouki et } \\
\text { al., 2003) }\end{array}$ \\
\hline \multirow{3}{*}{ Boreal Forest } & $\begin{array}{l}\text { Hyytiälä, Finland } \\
\text { EUCAARI } \\
\text { March - June, } 2007\end{array}$ & - & - & $8.5 \times 10^{-13}$ & $1.8^{\mathrm{b})}$ & $<0.5$ & $\begin{array}{l}\text { (Petäjä et al., } \\
\text { 2009) }\end{array}$ \\
\hline & \multirow{2}{*}{$\begin{array}{l}\text { Hyytiälä, Finland } \\
\text { HUMPPA-COPEC-2010 } \\
\text { Jul. - Aug., } 2010\end{array}$} & $0.6^{\text {d) }}$ & $\left.5.5 \times 10^{-3} \mathrm{~b}\right)$ & $8.5 \times 10^{-13}$ & $2.8^{d)}$ & $\approx 0.4$ & $\begin{array}{l}\text { (Mauldin III et } \\
\text { al., 2012) }\end{array}$ \\
\hline & & $0.03-0.3^{a)}$ & $\approx 10^{-2}$ a) & $8.06 \times 10^{-13}$ & $\approx 1^{\mathrm{a})}$ & $\approx 0.3$ & $\begin{array}{l}\text { (Boy et al., } \\
\text { 2013) }\end{array}$ \\
\hline $\begin{array}{l}\text { Moderately } \\
\text { polluted }\end{array}$ & $\begin{array}{l}\text { Tarrant County, TX, } \\
\text { Dallas-Fort Worth area } \\
\text { June } 2011\end{array}$ & $0.3^{\text {a) }}$ & - & $1.3 \times 10^{-12}$ & $\approx 2^{\mathrm{a})}$ & $<0.43$ & $\begin{array}{l}\text { (Kim et al., } \\
\text { 2015) }\end{array}$ \\
\hline
\end{tabular}

a) Estimated from presented data; ${ }^{\text {b) }}$ median; ${ }^{c}$ mean ${ }^{\text {d) }}$ mean taken from Novelli et al. (2017); ${ }^{\text {e) }}$ nucleation events 


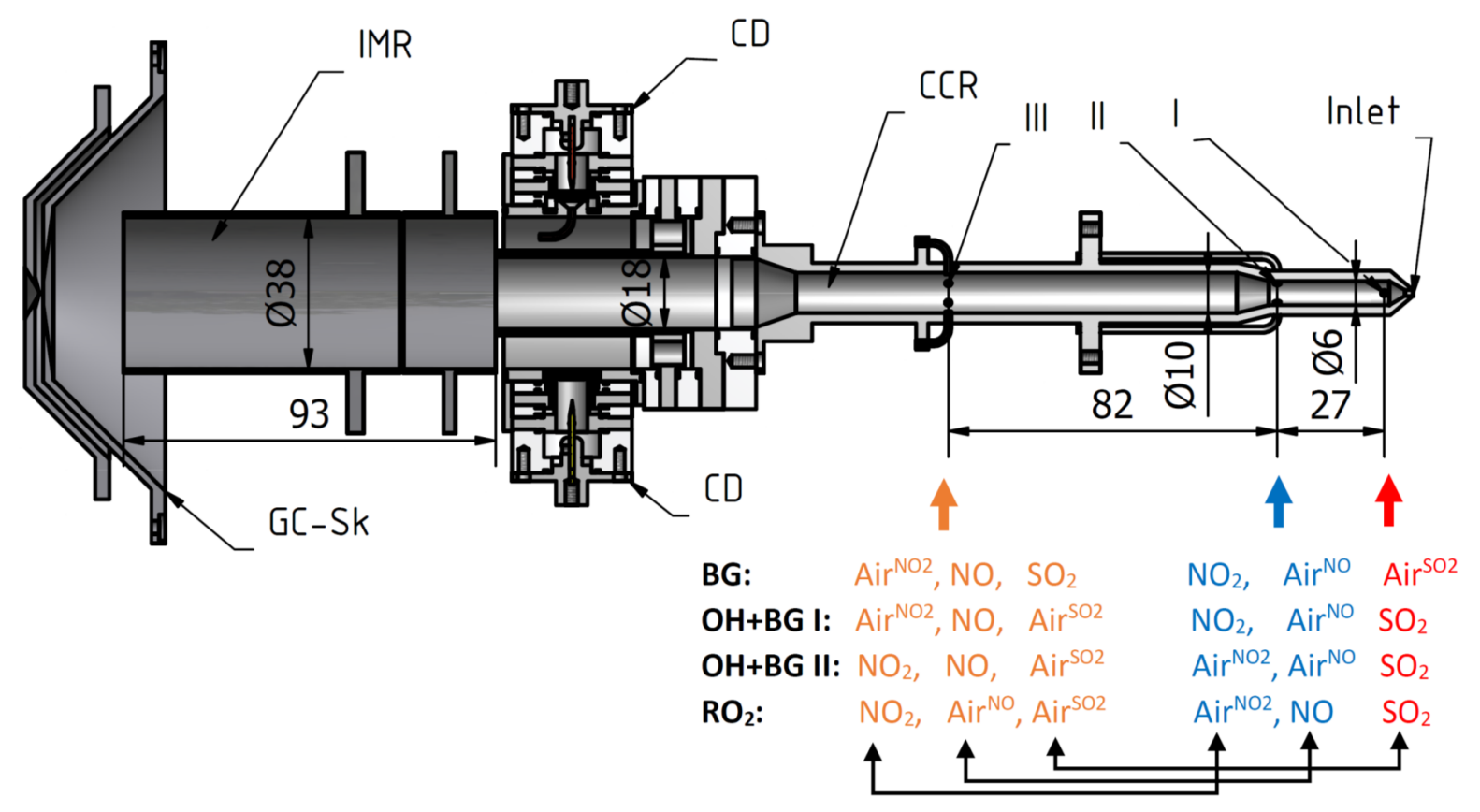

3 switchinq valves

Figure S1. Schema of the reactor comprising a sampling inlet, the chemical conversion reactor (CCR), the ion molecule reactor (IMR), the $\mathrm{NO}_{2} /$ Air or $\mathrm{NO}_{2} / \mathrm{N}_{2}$ corona discharge ion sources (CD) and a gas curtain / skimmer assembly (GC-Sk). Positions of the three injector assemblies are shown as I, II and III. The 3 switching valves are used to interchange the two inlet positions between the flows of $\mathrm{NO}_{2}, \mathrm{SO}_{2}$ and $\mathrm{NO}$ reactant mixtures and the corresponding equal flows of pure air $\mathrm{Air}^{\mathrm{NO} 2}$, $\mathrm{Air}^{\mathrm{SO} 2}$ and $\mathrm{Air}^{\mathrm{NO}}$, respectively. Switching of the $\mathrm{NO}_{2}, \mathrm{SO}_{2}$ and $\mathrm{NO}$ inlet positions allows for measurements in the background mode $(\mathrm{BG})$, the two different $\mathrm{OH}+\mathrm{BG}$ modes $(\mathrm{OH}+\mathrm{BG}$ $\mathrm{I}$ and $\mathrm{OH}+\mathrm{BG} \mathrm{II})$ and the $\left(\mathrm{RO}_{2}\right)$ mode. $\mathrm{OH}$ signal is derived from the difference of the signals measured in the $\mathrm{OH}+\mathrm{BG}$ I or the $\mathrm{OH}+\mathrm{BG}$ II and the BG modes. The $\mathrm{OH}+\mathrm{BG}$ I and $\mathrm{OH}+\mathrm{BG}$ II modes correspond to $\mathrm{OH}_{\text {to }} \mathrm{H}_{2} \mathrm{SO}_{4}$ chemical conversion times of $5 \mathrm{~ms}$ and $40 \mathrm{~ms}$, respectively. Concentrations of $\mathrm{SO}_{2}, \mathrm{NO}_{2}$ and $\mathrm{NO}$ in the CCR are $3 \times 10^{14} \mathrm{~cm}^{-3}, 1.2 \times 10^{16} \mathrm{~cm}^{-3}$ and $3 \times 10^{13} \mathrm{~cm}^{-3}$, respectively, corresponding to $\mathrm{OH}$ consumption by $\mathrm{SO}_{2}$ and $\mathrm{NO}_{2}$ of about $4 \mathrm{~ms}$ and $7 \mu \mathrm{s}$, respectively. Additional $\mathrm{NO}_{2}$ is added into the ion molecule rector via the ion source and with a flow of pure air sheath gas resulting in $\mathrm{NO}_{2}$ concentration in the IMR of $5 \times 10^{16} \mathrm{~cm}^{-3}$. Presence time in the IMR is of $0.45 \mathrm{~s}$. The reactor is made of stainless steel and Teflon isolation rings. 


\section{S3 Calibration of $\mathrm{OH}$ and $\mathrm{H}_{2} \mathrm{SO}_{4}$}

Calibration of $\mathrm{OH}$ is performed by producing known concentrations of $\mathrm{OH}$ by photolysis of $\mathrm{H}_{2} \mathrm{O}$ in air flow at $\lambda=184.9 \mathrm{~nm}$ :

$$
\begin{array}{ll}
\mathrm{H}_{2} \mathrm{O}+h v & \rightarrow \mathrm{H}+\mathrm{OH} \\
\mathrm{H}+\mathrm{O}_{2}+\mathrm{M} & \rightarrow \mathrm{HO}_{2}+\mathrm{M}
\end{array}
$$

The generated in this way $\mathrm{OH}$ concentration is quantified by chemical actinometry using photolysis of $\mathrm{N}_{2} \mathrm{O}$ at $\lambda=184.9 \mathrm{~nm}$ producing NO of measurable concentrations. Calibration system is based on the same principles that have been previously described in the literature, e.g. Dusanter et al. (2008), Kürten et al. (2012) and references therein). Below is given a detailed description of the calibration setup employed during the ChArMEx campaign in July-August 2013. This calibration system differs in several respects from the previously described calibration systems.

Measured signals $I^{\mathrm{OH}}$ and $I^{\mathrm{H}_{2} \mathrm{SO}_{4}}$ (see below) are related to $\mathrm{OH}$ and $\mathrm{H}_{2} \mathrm{SO}_{4}$ concentrations via calibration coefficients $C_{\mathrm{OH}}$ and $C_{\mathrm{H}_{2} \mathrm{SO}_{4}}$ :

$[\mathrm{OH}]=C_{\mathrm{OH}} \times I^{\mathrm{OH}}$

$\left[\mathrm{H}_{2} \mathrm{SO}_{4}\right]=C_{\mathrm{H}_{2} \mathrm{SO}_{4}} \times I^{\mathrm{H}_{2} \mathrm{SO}_{4}} ; \quad C_{\mathrm{H}_{2} \mathrm{SO}_{4}}=C_{\mathrm{SA}} \cdot C_{\mathrm{OH}}$

In the following we describe the calibration setup and methods used to derive $I^{\mathrm{OH}}$ and $I^{\mathrm{H}_{2} \mathrm{SO}_{4}}$ signals and to estimate $C_{\mathrm{OH}}, C_{\mathrm{H}_{2} \mathrm{SO}_{4}}$ and $C_{\mathrm{SA}}$ coefficients.

\section{S3.1 Calibration setup}

Essential elements of the calibration setup are presented in Figure S2. The whole setup is fixed on a frame allowing its placement in front of the instrument sampling aperture during field measurements or in a laboratory.

The photolysis of $\mathrm{H}_{2} \mathrm{O}$ or $\mathrm{N}_{2} \mathrm{O}$ is performed in a turbulent flow of humidified air or of $\mathrm{N}_{2} \mathrm{O} / \mathrm{N}_{2}$ mixtures, respectively, passing through a photolysis reactor cell (11) (Figure S2). The photolysis reactor cell of $50 \mathrm{~mm}$ in length makes a segment of a calibration stainless steel flow tube (2) of diameter $18 \mathrm{~mm}$. The rectangular volume illuminated by a mercury lamp (7) (Pen-Ray Lamp 11SC-1, UVP) is restricted by two $50 \mathrm{~mm}$ x $8 \mathrm{~mm}$ Heraeus Quarzglas Suprasil windows (10) fixed at a distance of $18 \mathrm{~mm}$ between them. The light from the Pen-Ray is passing through a $185 \mathrm{~nm}$ narrowband Acton Research $185-\mathrm{N}$ filter (8) $(0.1 \%$ transmission at $254 \mathrm{~nm} ; 18 \%$ transmission at $185 \mathrm{~nm}$ ) and through an adsorption cell (9) of length $3 \mathrm{~cm}$ which is fleshed either with $\mathrm{N}_{2} \mathrm{O} / \mathrm{N}_{2}$ mixtures or with pure nitrogen allowing to vary the $184.9 \mathrm{~nm}$ light intensity in the photolysis cell. Inner volume of the adsorption cell is divided into parallel channels of $4 \times 4 \mathrm{~mm}$ to reduce the light divergence. The light intensities on the exit from the photolysis cell and near the Pen-Ray lamp are monitored with two Hamamatsu R5764 phototubes (6) using homemade power supply and acquisition electronics. An enclosure surrounding the photolysis cell and other optical components as well as the compartment holding the Pen-Ray are flushed with nitrogen to avoid ozone formation.

The length of the flow tube section (2) between the photolysis cell and the end of the flow tube placed in front of the instrument sampling aperture (1) is variable from $5 \mathrm{~cm}$ to $35 \mathrm{~cm}$ in step of $5 \mathrm{~cm}$ to allow measurements of $\mathrm{OH}$ and $\mathrm{H}_{2} \mathrm{SO}_{4}$ wall loss rates (see below).

The humidified air or $\mathrm{N}_{2} \mathrm{O} / \mathrm{N}_{2}$ mixtures at flow rate of 24-40 $\operatorname{slm}(R e=1800-3000)$ are introduced into the inlet flow tube (4) via an entrance section (5) containing humidity and temperature sensors (Michell Instruments Optidew chilled mirror hygrometer and Vaisala capacitive DRYCAP dewpoint and temperature transmitter DMT340/347). The flow rates are controlled with Bronkhorst EL-FLOW mass flow controllers. Water is added to the flow of air using Bronkhorst water mass flow controllers (LIQUI-FLOW $24 \mathrm{~g} / \mathrm{h}$ and $\mu$-FLOW 1.4g/h). Addition of $\mathrm{SO}_{2}\left(5 \% \mathrm{SO}_{2} /\right.$ Air, Air Liquide) for $\mathrm{H}_{2} \mathrm{SO}_{4}$ calibration can be made either before the entrance section or after the photolysis cell via an injector in the end section of the flow tube. In-field calibration was usually performed using air and nitrogen ALPHAGAZ 2 and $\mathrm{N}_{2} \mathrm{O}$ N48 gases (Air Liquid). 


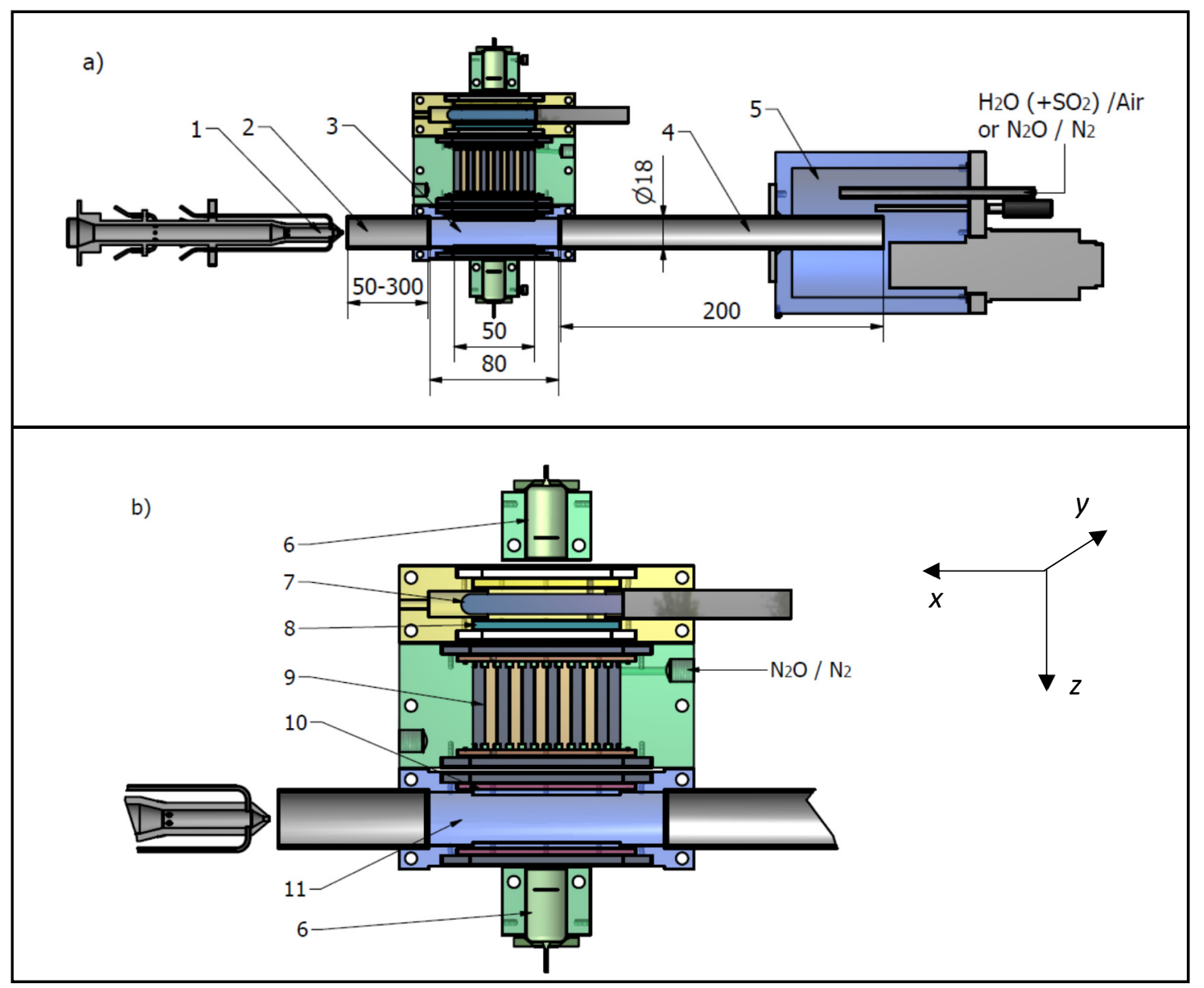

Figure S2. Schema of the calibration setup (a) and detailed view of the photolysis cell (b): 1 - inlet of CIMS; 2 calibration flow tube; 3 - photolysis cell; 4 - inlet flow tube; 5 - entrance volume with temperature and humidity sensors; 6 - phototubes; 7 - Hg Pen-Ray lamp; 8 - bandpass filter; 9 - $\mathrm{N}_{2} \mathrm{O}$ absorption cell; 10 - windows; 11 photolysis reactor cell.

\section{S3.2 Estimation of $\mathrm{OH}$ and $\mathrm{H}_{2} \mathrm{SO}_{4}$ concentrations produced by calibration setup}

Accounting for a fast turbulent mixing in the flow tube the concentration of $\mathrm{OH}$ on the exit of the photolysis cell is:

$[\mathrm{OH}]=\frac{1}{S} \iint_{y, z}\left(\int_{0}^{L} \psi(x, y, z) \sigma_{\mathrm{H}_{2} \mathrm{O}}\left[\mathrm{H}_{2} \mathrm{O}\right] \frac{d x}{v(x, y, z)}\right) \cdot d y \cdot d z$

Here, $\psi(x, y, z)$ and $v(x, y, z)$ are photon flux and flow velocity at point $x, y, z$ of the photolysis cell (Figure S2), respectively, $\sigma_{\mathrm{H}_{2} \mathrm{O}}$ is the absorption cross section of water at $184.9 \mathrm{~nm}, S$ is the area of the tube section in $y, z$ plane excluding viscous sublayer and integration is over $y, z$ of the illuminated region, also excluding viscous sublayer.

Assuming that all light rays are parallel in z direction, one can separate the dependence of $\psi$ on $z$ and $x, y$ accounting for the attenuation of the light at wavelength of $184.9 \mathrm{~nm}$ due to the adsorption by water and oxygen:

$\psi(x, y, z)=\psi_{0}(x, y) \exp \left(-\left(\sigma_{\mathrm{H}_{2} \mathrm{O}}\left[\mathrm{H}_{2} \mathrm{O}\right]+\sigma_{\mathrm{O}_{2}}\left[\mathrm{O}_{2}\right]\right) \cdot z\right)$

Also, assuming a flatness of the flow velocity profile in the turbulent core and assuming that the flow velocity is independent on $x$ and $y$ ( the width of illuminated volume in the cell is $8 \mathrm{~mm}$ compared to the tube diameter of 18 $\mathrm{mm}$ ) we obtain: 
$[\mathrm{OH}]=\frac{1}{S} \times \sigma_{\mathrm{H}_{2} \mathrm{O}}\left[\mathrm{H}_{2} \mathrm{O}\right] \times \Psi_{0}^{\mathrm{OH}} \times \int_{0}^{D_{\text {mrtb }}} \frac{\exp \left(-\left(\sigma_{\mathrm{H}_{2} \mathrm{O}}\left[\mathrm{H}_{2} \mathrm{O}\right]+\sigma_{\mathrm{O}_{2}}\left[\mathrm{O}_{2}\right]\right) \cdot z\right)}{v(z)} \cdot d z$

Here, $\Psi_{0}^{\mathrm{OH}}=\iint_{y, z} \psi_{0}(x, y) \cdot d y \cdot d z$ is the incident photon flux integrated over the entrance window area, $D_{\text {turb }}$ is the distance between the entrance and exit windows of the cell excluding viscous sublayer.

In case of $\mathrm{N}_{2} \mathrm{O}$ photolysis one can write a similar expression for the $\mathrm{NO}$ concentration:

$[\mathrm{NO}]=\frac{1}{S} \times \sigma_{\mathrm{N}_{2} \mathrm{O}}\left[\mathrm{N}_{2} \mathrm{O}\right] \times f\left(\mathrm{~N}_{2} \mathrm{O}\right) \times \Psi_{0}^{\mathrm{N}_{2} \mathrm{O}} \times \int_{0}^{D_{\text {urub }}} \frac{\exp \left(-\sigma_{\mathrm{N}_{2} \mathrm{O}}\left[\mathrm{N}_{2} \mathrm{O}\right] \cdot z\right)}{v(z)} \cdot d z$

Here, $f\left(\mathrm{~N}_{2} \mathrm{O}\right)$ is the yield of NO per one photon absorbed by $\mathrm{N}_{2} \mathrm{O}$ according to the reaction mechanism (SR0-SR3, see Table S2):

$$
f\left(\mathrm{~N}_{2} \mathrm{O}\right)=2 k_{3 a}\left[\mathrm{~N}_{2} \mathrm{O}\right] / k_{1}\left[\mathrm{O}_{2}\right]+k_{2}\left[\mathrm{~N}_{2}\right]+k_{3}\left[\mathrm{~N}_{2} \mathrm{O}\right]
$$

$$
\begin{array}{rlr}
\mathrm{N}_{2} \mathrm{O}+h v & \rightarrow \mathrm{N}_{2}+\mathrm{O}\left({ }^{1} \mathrm{D}\right) & (\mathrm{SR} 0) \\
\mathrm{O}\left({ }^{1} \mathrm{D}\right)+\mathrm{O}_{2} & \rightarrow \mathrm{O}\left({ }^{3} \mathrm{P}\right)+\mathrm{O}_{2} & (\mathrm{SR} 1) \\
\mathrm{O}\left({ }^{1} \mathrm{D}\right)+\mathrm{N}_{2} & \rightarrow \mathrm{O}\left({ }^{3} \mathrm{P}\right)+\mathrm{N}_{2} & (\mathrm{SR} 2) \\
\mathrm{O}\left({ }^{1} \mathrm{D}\right)+\mathrm{N}_{2} \mathrm{O} & \rightarrow \mathrm{NO}+\mathrm{NO} & (\mathrm{SR} 3 a) \\
& \rightarrow \mathrm{N}_{2}+\mathrm{O}_{2} & (\mathrm{SR} 3 b) \\
& \rightarrow \mathrm{O}\left({ }^{3} \mathrm{P}\right)+\mathrm{N}_{2} \mathrm{O} & (\mathrm{SR} 3 \mathrm{c})
\end{array}
$$

As the flow conditions are the same for $\mathrm{H}_{2} \mathrm{O}$ and $\mathrm{N}_{2} \mathrm{O}$ photolysis we can relate the $\mathrm{NO}$ and $\mathrm{OH}$ concentrations as:

$$
\frac{[\mathrm{OH}]}{[\mathrm{NO}]}=\frac{\Psi_{0}^{\mathrm{OH}}}{\Psi_{0}^{\mathrm{NO}}} \frac{\sigma_{\mathrm{H}_{2} \mathrm{O}}}{\sigma_{\mathrm{N}_{2} \mathrm{O}}} \frac{\left[\mathrm{H}_{2} \mathrm{O}\right]}{\left[\mathrm{N}_{2} \mathrm{O}\right] \cdot f\left(\mathrm{~N}_{2} \mathrm{O}\right)} \times\left\{\frac{\int_{0}^{D_{\text {wrb }}} \frac{\exp \left(-\left(\sigma_{\mathrm{H}_{2} \mathrm{O}}\left[\mathrm{H}_{2} \mathrm{O}\right]+\sigma_{\mathrm{O}_{2}}\left[\mathrm{O}_{2}^{H_{2} \mathrm{O}}\right]\right) \cdot z\right)}{v(z)} \cdot d z}{\int_{0}^{D_{\text {wrb }}} \frac{\exp \left(-\sigma_{\mathrm{N}_{2} \mathrm{O}}\left[\mathrm{N}_{2} \mathrm{O}\right] \cdot z\right)}{v(z)} \cdot d z}\right\}
$$

To evaluate the ratio of the integrals in (S8) we farther approximate the flow velocity profile of the turbulent core in $\mathrm{z}$ direction by a flat profile of a plug flow:

$$
[\mathrm{OH}]=\frac{[\mathrm{NO}]}{f\left(\mathrm{~N}_{2} \mathrm{O}\right)} \times \frac{\sigma_{\mathrm{H}_{2} \mathrm{O}}\left[\mathrm{H}_{2} \mathrm{O}\right]}{\sigma_{\mathrm{H}_{2} \mathrm{O}}\left[\mathrm{H}_{2} \mathrm{O}\right]+\sigma_{\mathrm{O}_{2}}\left[\mathrm{O}_{2}^{H_{2} \mathrm{O}}\right]} \times \frac{\Psi_{0}^{\mathrm{OH}}\left(1-\exp \left(-\left(\sigma_{\mathrm{H}_{2} \mathrm{O}}\left[\mathrm{H}_{2} \mathrm{O}\right]+\sigma_{\mathrm{O}_{2}}\left[\mathrm{O}_{2}^{H_{2} \mathrm{O}}\right]\right) D\right)\right)}{\Psi_{0}^{\mathrm{NO}}\left(1-\exp \left(-\left(\sigma_{\mathrm{N}_{2} \mathrm{O}}\left[\mathrm{N}_{2} \mathrm{O}\right]\right) D\right)\right)}
$$

In (S9), we neglect an influence of the viscous sublayer of thickness of about $1 \mathrm{~mm}$ at our flow conditions and assume that the absorption length is equal to the distance between the entrance and exit windows of the cell, $D_{\text {turb }}$ $\approx D$. The error of the ratio of the integrals in (S8) evaluated using the plug flow approximation is less than $1 \%$ for $\mathrm{N}_{2} \mathrm{O}$ volume fraction less than 0.5 . This was found by comparing the approximated and the numerically calculated integrals using turbulent flow velocity profile consisting of viscous sublayer $(\mathrm{y}+<5)$, buffer layer $(5<\mathrm{y}+<30)$ and logarithmic low region $(\mathrm{y}+>30)$ (Tennekes and Lumley, 1972).

Finally, accounting for first order losses of $\mathrm{OH}$ (e.g. wall loss or reactions with impurities) and using the proportionality of the total photon flux and the measured phototube current we obtain for the $\mathrm{OH}$ concentration at the exit of the flow tube: 


$$
[\mathrm{OH}]=\frac{I_{185}\left(\exp \left(\left(\sigma_{\mathrm{H}_{2} \mathrm{O}}\left[\mathrm{H}_{2} \mathrm{O}\right]+\sigma_{\mathrm{O}_{2}}\left[\mathrm{O}_{2}\right]\right) D\right)-1\right)}{1+\sigma_{\mathrm{O}_{2}}\left[\mathrm{O}_{2}\right] / \sigma_{\mathrm{H}_{2} \mathrm{O}}\left[\mathrm{H}_{2} \mathrm{O}\right]} \times C_{\mathrm{N}_{2} \mathrm{O}} \times C_{\text {loss }}^{\text {cll }} \times C_{\text {loss }}^{\text {thbe }}
$$

Where, $I_{185}$ is the phototube current proportional to the total photon flux at $184.9 \mathrm{~nm}$ (see comment in section 3.4.2) on the exit of the photolysis reactor cell and $C_{\mathrm{N}_{2} \mathrm{O}}$ is the calibration coefficient derived from the yield of NO in the photolysis of $\mathrm{N}_{2} \mathrm{O}$ :

$$
C_{\mathrm{N}_{2} \mathrm{O}}=\frac{[\mathrm{NO}]}{\Delta I^{\mathrm{NO}} \times f\left(\mathrm{~N}_{2} \mathrm{O}\right)}
$$

Here, $\Delta I^{\mathrm{NO}}$ is the difference of the phototube current in absence and in presence of $\mathrm{N}_{2} \mathrm{O}$ and $f\left(\mathrm{~N}_{2} \mathrm{O}\right)$ is the yield of $\mathrm{NO}$ by photolysis of $\mathrm{N}_{2} \mathrm{O}$ defined above by the equation (S7).

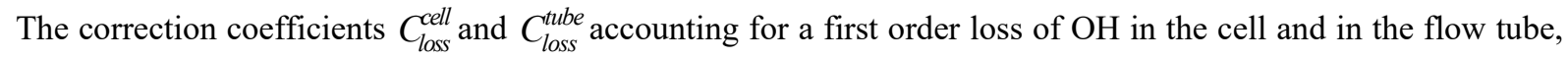
respectively, can be easily derived from differential equation describing $\mathrm{OH}$ production and the first order loss:

$$
\begin{aligned}
& C_{\text {loss }}^{\text {cell }}=\left(\frac{1-\exp \left(-K_{\mathrm{OH}} \cdot t_{\text {cell }}\right)}{K_{\mathrm{OH}} \cdot t_{\text {cell }}}\right) \\
& C_{\text {loss }}^{\text {tube }}=\exp \left(-K_{\mathrm{OH}} \cdot t\right)
\end{aligned}
$$

In (S12) and (S13), $K_{\mathrm{OH}}$ is a first order $\mathrm{OH}$ loss rate coefficient, $t_{c e l l}$ and $t$ are the presence times in the cell and in the flow tube end section, respectively, calculated from corresponding lengths and bulk flow velocity. In absence of $\mathrm{SO}_{2}$ being added to the flow for $\mathrm{H}_{2} \mathrm{SO}_{4}$ calibration the $\mathrm{OH}$ loss is explained predominantly by the wall losses, $K_{\mathrm{OH}}=K_{\mathrm{OH}}^{W}$.

Estimation of $\mathrm{OH}$ concentration according to (S10) is made using measured phototube current and $\mathrm{H}_{2} \mathrm{O}$

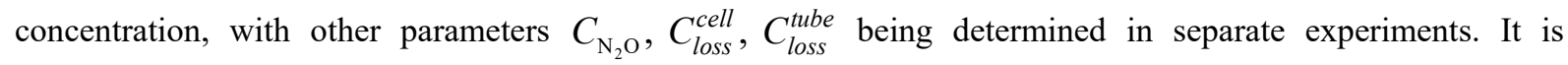
important to note that calibration of the phototube is not required. It is essential, however, that sensitivity of the phototube remains unchanged after determination of $C_{\mathrm{N}_{2} \mathrm{O}}$.

For $\mathrm{H}_{2} \mathrm{SO}_{4}$ calibration $\mathrm{OH}$ is converted to $\mathrm{H}_{2} \mathrm{SO}_{4}$ by adding $\mathrm{SO}_{2}$ to the flow tube. In this case $\mathrm{OH}$ concentration is also described by (S10), but with $\mathrm{OH}$ loss coefficient taking into account $\mathrm{OH}$ wall loss and $\mathrm{OH}$ consumption in the reaction of $\mathrm{OH}$ with $\mathrm{SO}_{2}$ :

$$
K_{\mathrm{OH}}=K_{\mathrm{OH}}^{W}+k_{\mathrm{OH}+\mathrm{SO}_{2}} \cdot\left[\mathrm{SO}_{2}\right]
$$

Solving differential equation for $\mathrm{H}_{2} \mathrm{SO}_{4}$ accounting for $\mathrm{H}_{2} \mathrm{SO}_{4}$ production in the reaction of $\mathrm{OH}$ with $\mathrm{SO}_{2}$ and its first order loss on the walls of the flow tube we obtain:

$$
\left[\mathrm{H}_{2} \mathrm{SO}_{4}\right]=[\mathrm{OH}] \times k_{\mathrm{OH}+\mathrm{SO}_{2}} \cdot\left[\mathrm{SO}_{2}\right] \cdot \frac{e^{\left(K_{\mathrm{OH}}-K_{\mathrm{SA}}\right) \cdot t}}{\left(1-e^{-K_{\mathrm{OH}} \cdot t_{c e l l}}\right)} \cdot\left(\frac{1}{K_{\mathrm{SA}}}-\frac{K_{\mathrm{OH}} e^{-K_{\mathrm{SA}} \cdot t_{c e l l}}}{K_{\mathrm{SA}}\left(K_{\mathrm{OH}}-K_{\mathrm{SA}}\right)}+\frac{1+e^{K_{\mathrm{SA}} \cdot t} e^{-K_{\mathrm{OH}}\left(t_{\text {cell }}+t\right)}-e^{\left(K_{\mathrm{SA}}-K_{\mathrm{OH}}\right) \cdot t}}{\left(K_{\mathrm{OH}}-K_{\mathrm{SA}}\right)}\right)
$$

Where $[\mathrm{OH}]$ is the $\mathrm{OH}$ concentration described by $(\mathrm{S} 10)$ with $K_{\mathrm{OH}}$ according to (S14) and $K_{\mathrm{SA}}$ is the $\mathrm{H}_{2} \mathrm{SO}_{4}$ first order wall loss rate coefficient.

Photodissociation of $\mathrm{SO}_{2}$ at $184.9 \mathrm{~nm}$ may lead to $\mathrm{SO}_{3}$ and, hence, additional $\mathrm{H}_{2} \mathrm{SO}_{4}$ formation according to the reactions (SR4 - SR6). This contribution is higher for higher ratio of $\left[\mathrm{SO}_{2}\right]$ to $\left[\mathrm{H}_{2} \mathrm{O}\right]$. Using the listed here rate coefficients and $\mathrm{SO}_{2}$ photodissociation cross section the maximum contribution to $\mathrm{H}_{2} \mathrm{SO}_{4}$ formation from the $\mathrm{SO}_{2}$ photolysis was estimated to be about $0.8 \%$ at relative humidity of $10 \%$ and $\mathrm{SO}_{2}$ concentration of $5 \times 10^{13} \mathrm{~cm}^{-3}$. In all calibration experiments the ratio $\left[\mathrm{SO}_{2}\right] /\left[\mathrm{H}_{2} \mathrm{O}\right]$ was maintained low enough to keep the contribution of $\mathrm{SO}_{2}$ photodissociation to $\mathrm{H}_{2} \mathrm{SO}_{4}$ formation lower than $1 \%$. 
$\mathrm{SO}_{2}+h v \quad \rightarrow \quad \mathrm{SO}+\mathrm{O} \quad(\mathrm{SR} 4) \quad 3.11 \times 10^{-18} \mathrm{~cm}^{2}$ (Danielache et al., 2008).

$\mathrm{O}+\mathrm{SO}_{2}+\mathrm{M} \rightarrow \mathrm{SO}_{3}+\mathrm{M} \quad(\mathrm{SR} 5) \quad 1.3 \times 10^{-14} \mathrm{~cm}^{3}$ molecule ${ }^{-1} \mathrm{~s}^{-1}$ (Burkholder et al., 2015)

$\mathrm{SO}+\mathrm{O}_{2} \quad \rightarrow \quad \mathrm{SO}_{2}+\mathrm{O} \quad$ (SR6a) $7.6 \times 10^{-17} \mathrm{~cm}^{3}$ molecule ${ }^{-1} \mathrm{~s}^{-1}$ (Atkinson et al., 2004)

$\mathrm{SO}+\mathrm{O}_{2}+\mathrm{M} \rightarrow \mathrm{SO}_{3}+\mathrm{M} \quad(\mathrm{SR} 6 \mathrm{~b})<10^{-36} \mathrm{~cm}^{6}$ molecule $\mathrm{s}^{-1}$ (Black et al., 1982; Whitehill et al., 2015)

At maximum used $\mathrm{SO}_{2}$ concentration of $5 \times 10^{13} \mathrm{~cm}^{-3}$ attenuation of light at $184.9 \mathrm{~nm}$ by $\mathrm{SO}_{2}$ can be neglected.

\section{S3.3 Mass peaks intensities and $\mathrm{OH}, \mathrm{H}_{2} \mathrm{SO}_{4}$ concentrations}

To distinguish ambient $\mathrm{H}_{2} \mathrm{SO}_{4}$ and $\mathrm{H}_{2} \mathrm{SO}_{4}$ produced by chemical conversion of $\mathrm{OH}$ the conversion is performed with ${ }^{34} \mathrm{SO}_{2}$ added into the CCR of the CIMS instrument. $\mathrm{OH}$ and $\mathrm{H}_{2} \mathrm{SO}_{4}$ are derived from measurement of peak intensities $I_{62}\left(\mathrm{~m} / \mathrm{z}=62, \mathrm{NO}_{3}{ }^{-}\right), I_{97}\left(\mathrm{~m} / \mathrm{z}=97, \mathrm{H}^{32} \mathrm{SO}_{4}{ }^{-}\right)$and $I_{99}\left(\mathrm{~m} / \mathrm{z}=99, \mathrm{H}^{34} \mathrm{SO}_{4}{ }^{-}\right)$. Accounting for the isotopic composition of $\mathrm{SO}_{2}$ used for the chemical conversion (99\% isotopic enrichment of ${ }^{34} \mathrm{~S}$, EURISO-TOP) and sulphur and oxygen isotope natural abundance ( $94 \%$ and $5 \%$ for $\mathrm{HSO}_{4} \mathrm{~m} / \mathrm{z}=97$ and $\mathrm{m} / \mathrm{z}=99$, respectively) the measured $I_{62}, I_{97}$ and $I_{99}$ are related to $\mathrm{OH}$ and $\mathrm{H}_{2} \mathrm{SO}_{4}$ concentrations as follows:

$$
\begin{aligned}
& I_{97} / I_{62}=0.94 \cdot \frac{1}{C_{\mathrm{H}_{2} \mathrm{SO}_{4}}} \cdot\left[\mathrm{H}_{2} \mathrm{SO}_{4}\right]+\frac{1}{C_{\mathrm{OH}}} \cdot\left(\frac{0.01 \cdot\left[\mathrm{SO}_{2}\right]^{C C R}+0.94 \cdot\left[\mathrm{SO}_{2}\right]^{E x t}}{\left[\mathrm{SO}_{2}\right]^{C C R}+\left[\mathrm{SO}_{2}\right]^{E x t}}\right) \cdot[\mathrm{OH}] \\
& I_{99} / I_{62}=0.05 \cdot \frac{1}{C_{\mathrm{H}_{2} \mathrm{SO}_{4}}} \cdot\left[\mathrm{H}_{2} \mathrm{SO}_{4}\right]+\frac{1}{C_{\mathrm{OH}}} \cdot\left(\frac{0.99 \cdot\left[\mathrm{SO}_{2}\right]^{C C R}+0.05 \cdot\left[\mathrm{SO}_{2}\right]^{E x t}}{\left[\mathrm{SO}_{2}\right]^{C C R}+\left[\mathrm{SO}_{2}\right]^{E x t}}\right) \cdot[\mathrm{OH}]
\end{aligned}
$$

Here, indexes $F T$ and $C C R$ indicate concentrations of $\mathrm{SO}_{2}$ in the calibration flow tube reactor (or ambient concentration of $\mathrm{SO}_{2}$ ) and in the CCR, respectively. $C_{\mathrm{OH}}$ and $C_{\mathrm{H}_{2} \mathrm{SO}_{4}}$ are the calibration coefficients defined by (S1) and (S2). Then, combinations of $I_{97}$ and $I_{99}$ corresponding to $\mathrm{OH}$ and $\mathrm{H}_{2} \mathrm{SO}_{4}$ concentrations are calculated as follows:

$$
\begin{aligned}
& I^{\mathrm{OH}}=\frac{1}{C_{\mathrm{OH}}} \cdot[\mathrm{OH}]=\frac{\left(\frac{I_{99}}{I_{62}}-\frac{0.05}{0.94} \cdot \frac{I_{97}}{I_{62}}\right)}{\left(0.99-0.01 \cdot \frac{0.05}{0.94}\right)} \cdot\left(1+\frac{\left[\mathrm{SO}_{2}\right]^{E x t}}{\left[\mathrm{SO}_{2}\right]^{C C R}}\right) \\
& I^{\mathrm{H}_{2} \mathrm{SO}_{4}}=\frac{1}{C_{\mathrm{H}_{2} \mathrm{SO}_{4}}} \cdot\left[\mathrm{H}_{2} \mathrm{SO}_{4}\right]=\frac{1}{0.94} \cdot \frac{I_{97}}{I_{62}}-\frac{\left(\frac{I_{99}}{I_{62}}-\frac{0.05}{0.94} \cdot \frac{I_{97}}{I_{62}}\right)}{\left(0.99-0.01 \cdot \frac{0.05}{0.94}\right)} \cdot\left(\frac{0.01}{0.94}+\frac{\left[\mathrm{SO}_{2}\right]^{E x t}}{\left[\mathrm{SO}_{2}\right]^{C C R}}\right)
\end{aligned}
$$

For ambient measurements, when $\frac{\left[\mathrm{SO}_{2}\right]^{E x t}}{\left[\mathrm{SO}_{2}\right]^{C C R}}$ is typically less than $10^{-4},(\mathrm{~S} 18)$ and (S19) can be simplified:

$$
\begin{gathered}
I^{\mathrm{OH}}=\frac{1}{0.99} \cdot \frac{I_{99}}{I_{62}}-\frac{0.05}{0.99 \cdot 0.94} \cdot \frac{I_{97}}{I_{62}} \\
I^{\mathrm{H}_{2} \mathrm{SO}_{4}}=\frac{1}{0.94} \cdot \frac{I_{97}}{I_{62}}-\frac{0.01}{0.99 \cdot 0.94} \cdot \frac{I_{99}}{I_{62}}
\end{gathered}
$$




\section{S3.4 Calibration example}

\section{S3.4.1 OH and $\mathrm{H}_{2} \mathrm{SO}_{4}$ wall loss rates}

The wall loss rate coefficients are determined by measuring the dependence of $\mathrm{OH}$ or $\mathrm{H}_{2} \mathrm{SO}_{4}$ signal intensities on the length of the end section of the flow tube (varied from $5 \mathrm{~cm}$ to $35 \mathrm{~cm}$ with a step of $5 \mathrm{~cm}$ (Figure S3). High concentration of $\mathrm{SO}_{2}$, in these experiments, of up to $5 \times 10^{14} \mathrm{~cm}^{-3}$, was used for fast conversion of $\mathrm{OH}_{\text {into }} \mathrm{H}_{2} \mathrm{SO}_{4}$.

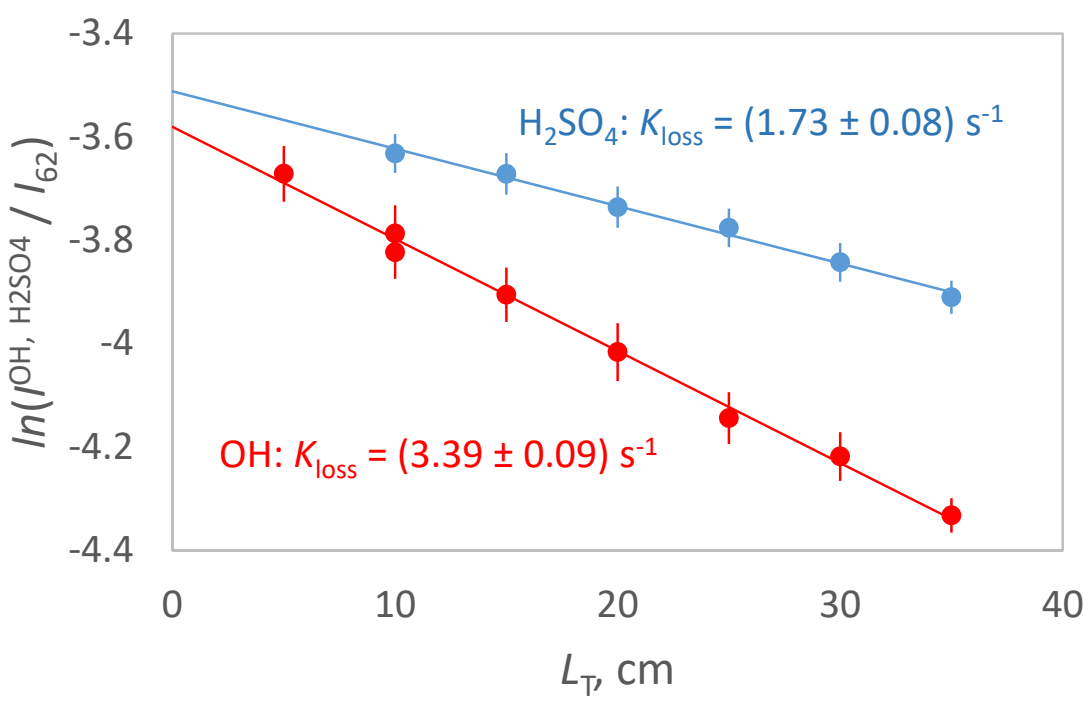

Figure S3. Example of wall loss decay rate measurements: red - $\mathrm{OH}$ decay at $\mathrm{RH}=43 \%$; blue $-\mathrm{H}_{2} \mathrm{SO}_{4}$ decay at $\mathrm{RH}=45 \%$ and $\left[\mathrm{SO}_{2}\right]=5 \times 10^{14} \mathrm{~cm}^{-3}$.

\section{S3.4.2 Determination of $C_{\mathrm{N}_{2} \mathrm{O}}$ from $\mathrm{N}_{2} \mathrm{O}$ photolysis}

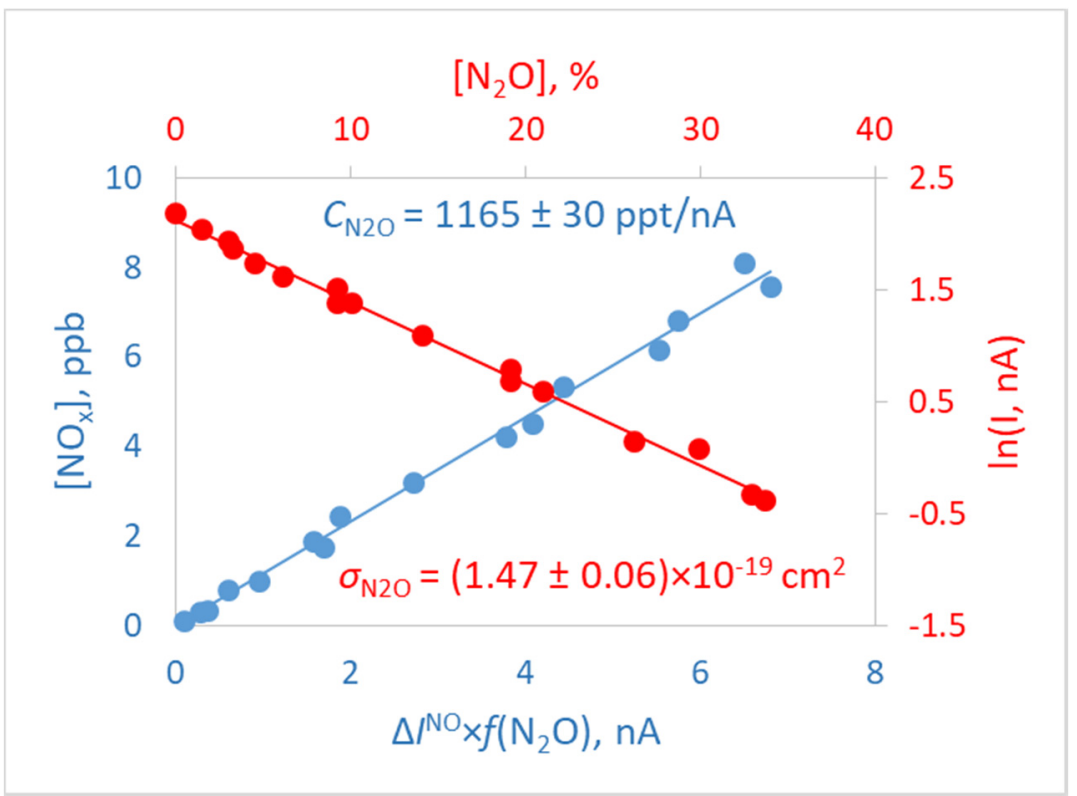

Figure S4. Determination of the calibration coefficient $C_{\mathrm{N}_{2} \mathrm{O}}$ by measuring $\left[\mathrm{NO}_{\mathrm{x}}\right]$ from the photolysis of $\mathrm{N}_{2} \mathrm{O}$ at $184.9 \mathrm{~nm}$ as a function on $\Delta I^{\mathrm{NO}} \times f\left(\mathrm{~N}_{2} \mathrm{O}\right)$ (blue points). Red points represent dependence of the phototube current on $\mathrm{N}_{2} \mathrm{O}$ concentration. Absorption cross section of $\mathrm{N}_{2} \mathrm{O}$ obtained from this dependence is in agreement with the literature value of $1.43 \times 10^{-19} \mathrm{~cm}^{2}$ (Creasey et al., 2000). 
$\mathrm{NO}$ generated by $\mathrm{N}_{2} \mathrm{O}$ photolysis was measured using Ecotech EC9841T NOx Trace Analyser. The lower detection limit of this analyser was estimated to be about $100 \mathrm{ppt}(10 \mathrm{~min}$ integration time, $1 \sigma$ at $\mathrm{S} / \mathrm{N}=1)$. To produce sufficient $\mathrm{NO}$ concentrations the $\mathrm{N}_{2} \mathrm{O}$ photolysis was conducted without the $185 \mathrm{~nm}$ bandpass filter, while the production of $\mathrm{OH}$ by the photolysis of $\mathrm{H}_{2} \mathrm{O}$ was performed with the filter installed to allow using of water vapour concentrations high enough for a reliable $\mathrm{H}_{2} \mathrm{O}$ measurements. In both cases the contribution of the strongest emission line of the mercury Pen-Ray lamp at $254 \mathrm{~nm}$ to the measured with the phototube photocurrent was not negligible. As the absorption by $\mathrm{N}_{2} \mathrm{O}$ at $254 \mathrm{~nm}$ is negligible, this contribution was determined from the dependence of the photocurrent on the concentration of $\mathrm{N}_{2} \mathrm{O}$ in the absorption cell of the calibrator and was found to be of $(56 \pm 2) \%$ and of $(5.10 \pm 0.05) \%$ for the configurations without and with filter, respectively (during the ChArMEx campaign).

\section{S3.4.3 Calibration of $\mathrm{OH}$ and $\mathrm{H}_{2} \mathrm{SO}_{4}$}

In Figure $\mathrm{S} 5$ is presented an example of a typical calibration procedure consisting of measurement of dependences of $I^{\mathrm{OH}}$ and $I^{\mathrm{H} 2 \mathrm{SO} 4}$ defined in (S18) and (S19) on the photolysis light intensity and concentrations of $\mathrm{H}_{2} \mathrm{O}$ and $\mathrm{SO}_{2}$ in the calibration flow tube.

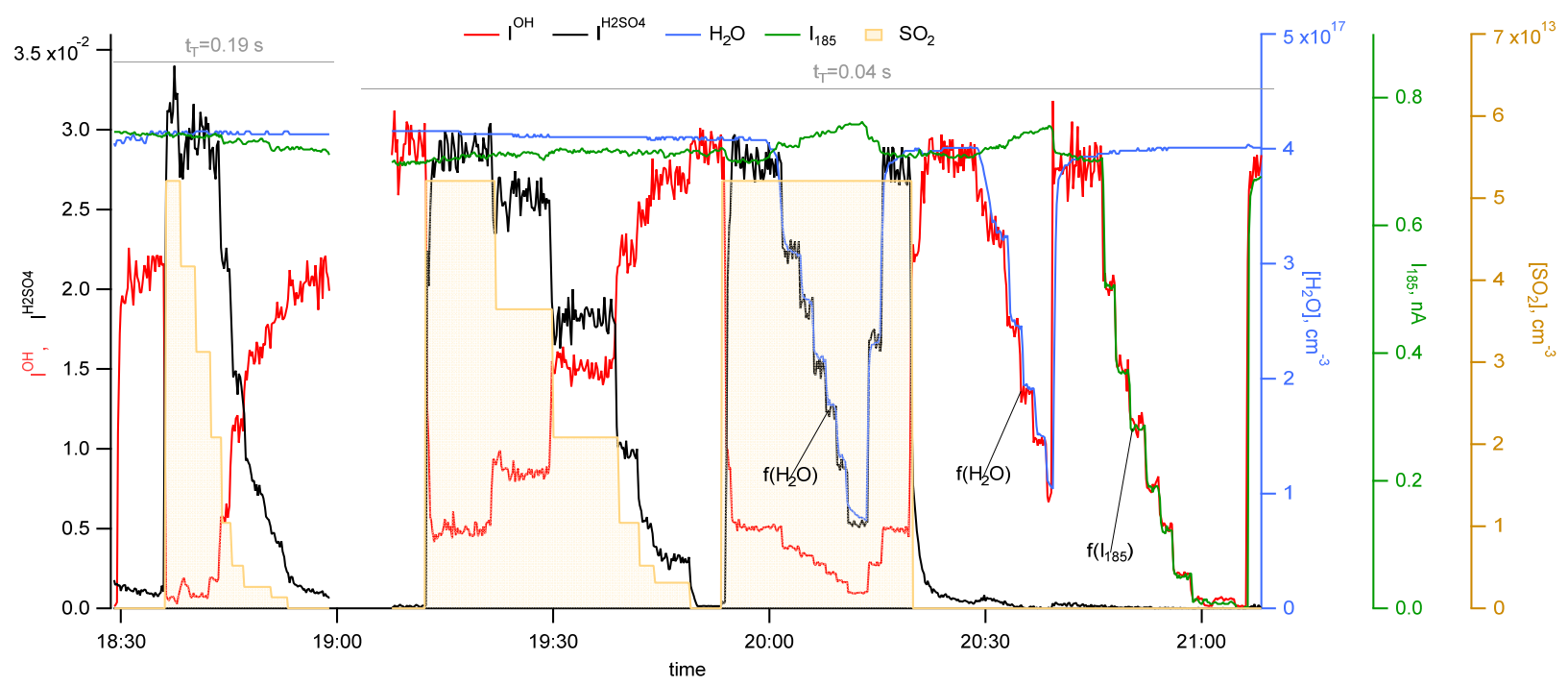

Figure S5. Example of "fast" field calibration of $\mathrm{OH}$ and $\mathrm{H}_{2} \mathrm{SO}_{4}$ including conversion of $\mathrm{OH}$ to $\mathrm{H}_{2} \mathrm{SO}_{4}$ at different $\mathrm{SO}_{2}$ concentrations and dependencies of $\mathrm{OH}$ and $\mathrm{H}_{2} \mathrm{SO}_{4}$ signals on $\left[\mathrm{H}_{2} \mathrm{O}\right]$ and of $\mathrm{OH}$ signal on light intensity $I_{185}$. The conversion of $\mathrm{OH}$ to $\mathrm{H}_{2} \mathrm{SO}_{4}$ was conducted at two calibration reactor lengths corresponding to reaction time of $0.19 \mathrm{~s}$ and $0.04 \mathrm{~s}$.

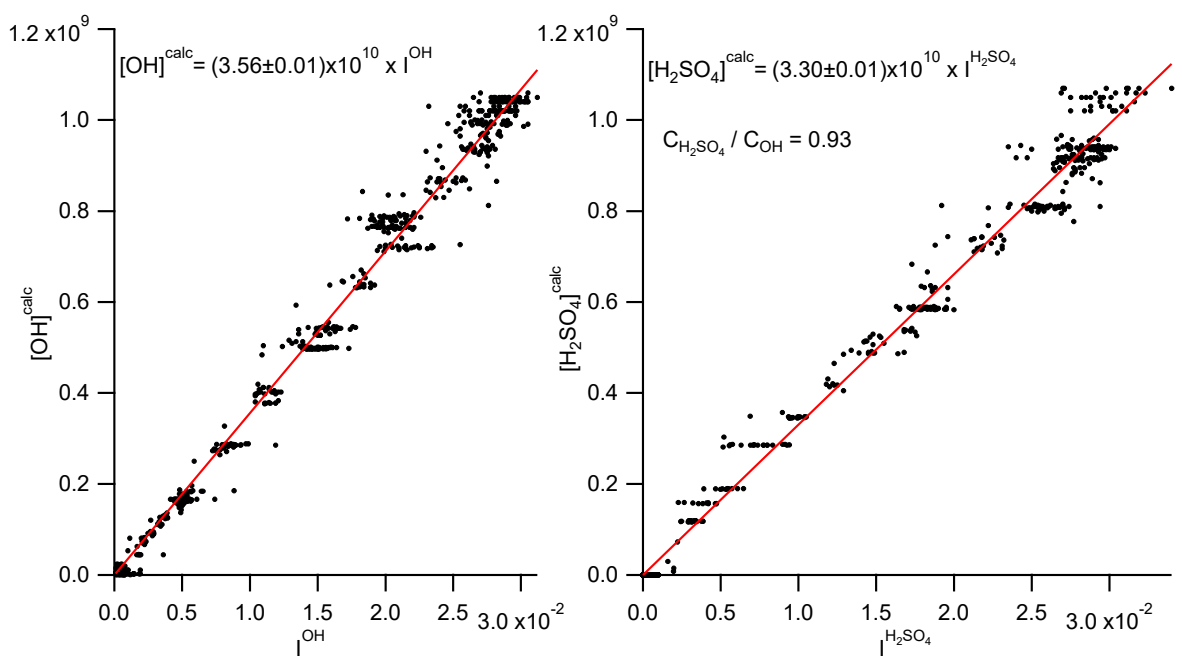

Figure S6. Comparison of all measured $I^{\mathrm{OH}}$ and $I^{\mathrm{H} 2 \mathrm{SO} 4}$ shown in Figure $\mathrm{S} 4$ with calculated $[\mathrm{OH}]$ and $\left[\mathrm{H}_{2} \mathrm{SO}_{4}\right]$. 
The calibration coefficients $C_{\mathrm{OH}}$ and $C_{\mathrm{H}_{2} \mathrm{SO}_{4}}$ can be determined by comparing the measured $I^{\mathrm{OH}}$ and $I^{\mathrm{H} 2 \mathrm{SO} 4}$ with $[\mathrm{OH}]$ and $\left[\mathrm{H}_{2} \mathrm{SO}_{4}\right]$ calculated according to $(\mathrm{S} 10)$ and $(\mathrm{S} 15)$, as shown in Figure S6 and Figure S7.

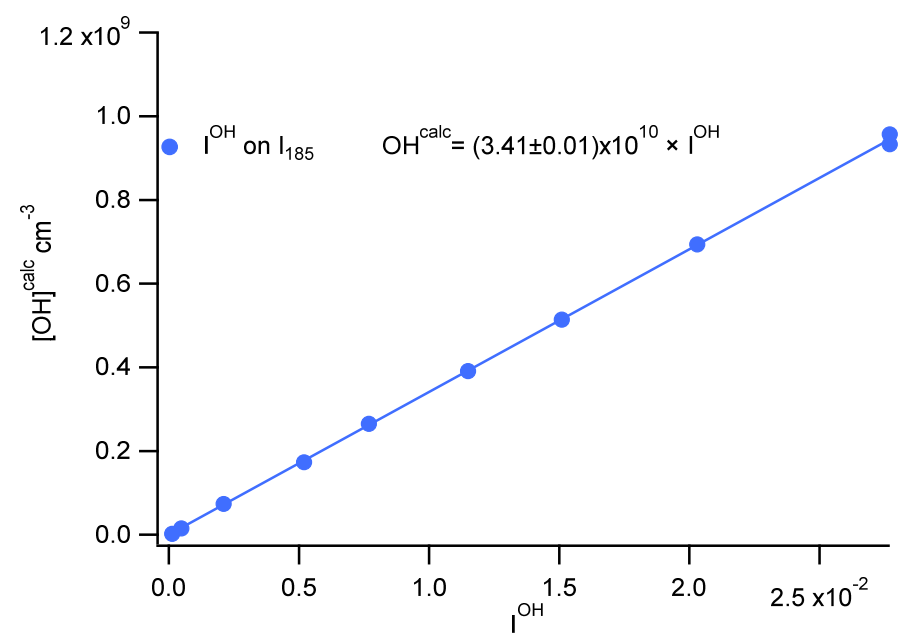

Figure S7. Example of $\mathrm{OH}$ calibration coefficient determination from the dependence of $\mathrm{I}^{\mathrm{OH}}$ on light intensity using data presented in Figure S5.

In practice, the calibration coefficient $C_{\mathrm{OH}}$ is determined in absence of $\mathrm{SO}_{2}$ (e.g. as shown in Figure S7) while the ratio $C_{\mathrm{SA}}=C_{\mathrm{H} 2 \mathrm{SO} 4} / C_{\mathrm{OH}}$ is determined by fitting measured ratios of $I^{\mathrm{H} 2 \mathrm{SO} 4} / \Delta I^{\mathrm{OH}}$ to the calculated ratios of $\left[\mathrm{H}_{2} \mathrm{SO}_{4}\right] / \Delta[\mathrm{OH}]$ at different $\left[\mathrm{SO}_{2}\right]^{R}$, as shown in Figure $\mathrm{S} 8 . \Delta[\mathrm{OH}]$ and $\Delta I^{\mathrm{OH}}$ correspond to a difference of the calculated $[\mathrm{OH}]$ and the measured $I_{\mathrm{OH}}$, respectively, in absence and presence of $\mathrm{SO}_{2}$. Determined in this way, the $C_{\mathrm{OH}}$ calibration coefficient is independent on the value used for the $\mathrm{OH}+\mathrm{SO}_{2}$ rate coefficient while the ratio $C_{\mathrm{SA}}$ $=C_{\mathrm{H} 2 \mathrm{SO} 4} / C_{\mathrm{OH}}$ is independent on the sensitivity to $\mathrm{OH}$ and only slightly depends on the value of the $k_{\mathrm{OH}+\mathrm{SO} 2}$ as shown in Figure S8.

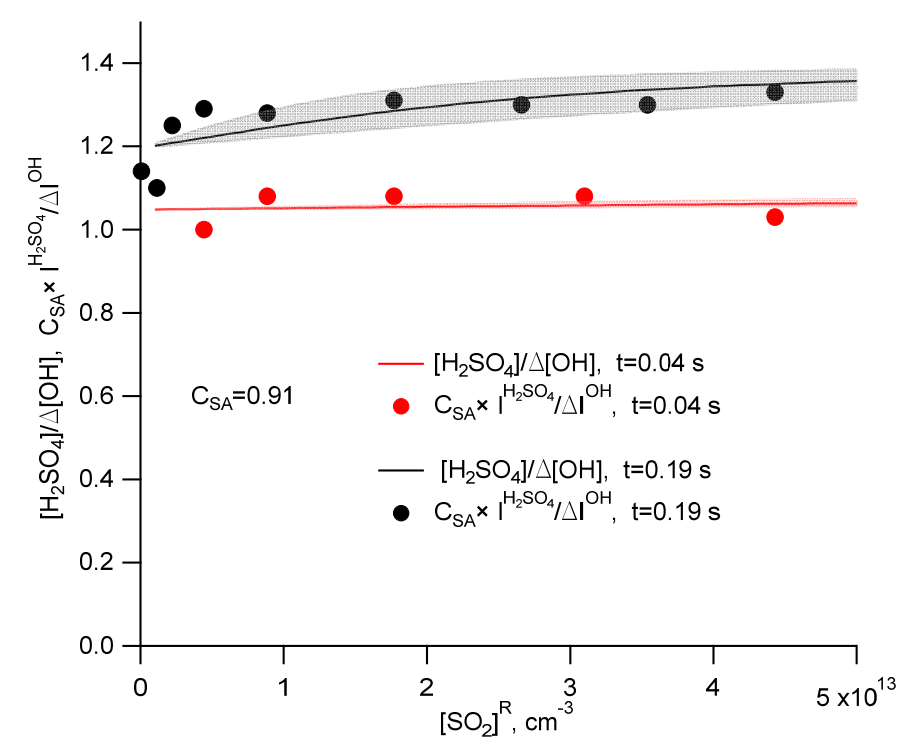

Figure S8. Calibration of relative sensitivity of $\mathrm{OH}$ and $\mathrm{H}_{2} \mathrm{SO}_{4}$ : dependencies of calculated (lines) and measured (dots) ratios of the generated $\mathrm{H}_{2} \mathrm{SO}_{4}$ to the $\mathrm{OH}$ consumption on the $\mathrm{SO}_{2}$ concentration in the calibration flow tube reactor. Red and black colors correspond to the shorter and the longer flow tubes, respectively. Shadowed gray and red regions show sensitivity to the used rate coefficient of the reaction $\mathrm{OH}+\mathrm{SO}_{2}$ : upper and lower boundaries correspond to the rate constant multiplied and divided by 2. Larger ratio of $\mathrm{H}_{2} \mathrm{SO}_{4}$ to $\Delta \mathrm{OH}$ at the shorter reaction time is explained by faster wall loss of $\mathrm{OH}$ compared to $\mathrm{H}_{2} \mathrm{SO}_{4}$. 
S3.5 Photochemical coefficients and uncertainty estimation.

Table S2. Photochemical coefficients used for the calculation of $\mathrm{OH}$ and $\mathrm{H}_{2} \mathrm{SO}_{4}$

\begin{tabular}{|l|l|l|l|}
\hline Parameter & Value & Uncertainty $(1 \sigma)$ & Reference \\
\hline$\sigma_{\mathrm{H}_{2} \mathrm{O}}$ & $(7.22 \pm 0.22) \times 10^{-20} \mathrm{~cm}^{2}$ & $3 \%$ & (Creasey et al., 2000) \\
\hline$\sigma_{\mathrm{O}_{2}}$ & $(1.14 \pm 0.05) \times 10^{-20} \mathrm{~cm}^{2}$ & $5 \%$ & (Creasey et al., 2000) \\
\hline$\sigma_{\mathrm{N}_{2} \mathrm{O}}$ & $(1.43 \pm 0.02) \times 10^{-19} \mathrm{~cm}^{2}$ & $2 \%$ & (Creasey et al., 2000) \\
\hline $\mathrm{SR} 1, k_{1}$ & $3.3 \times 10^{-11} \exp (-55 / \mathrm{T}) \mathrm{cm}^{3} \mathrm{~s}^{-1}$ & $10 \%$ & (Sander et al., 2011) \\
\hline $\mathrm{SR} 2, k_{2}$ & $2.5 \times 10^{-11} \exp (-110 / \mathrm{T}) \mathrm{cm}^{3} \mathrm{~s}^{-1}$ & $10 \%$ & (Sander et al., 2011) \\
\hline $\mathrm{SR} 3, k_{3}$ & $1.19 \times 10^{-10} \exp (-20 / \mathrm{T}) \mathrm{cm}^{3} \mathrm{~s}^{-1}$ & $10 \%$ & (Sander et al., 2011) \\
\hline $\mathrm{SR} 3 a, k_{3 \mathrm{a}}$ & $7.25 \times 10^{-11} \exp (-20 / \mathrm{T}) \mathrm{cm}^{3} \mathrm{~s}^{-1}$ & $10 \%$ & (Sander et al., 2011) \\
\hline $\mathrm{k}_{\mathrm{OH}+\mathrm{SO} 2}$ & $8.06 \times 10^{-13} \mathrm{~cm}^{3} \mathrm{~s}^{-1}\left(760 \mathrm{torr}_{2} 298 \mathrm{~K}\right)$ & $25 \% *)$ & (Atkinson et al., 2004) \\
\hline
\end{tabular}

*) estimated (see discussion in the article)

Table S3. Estimation of uncertainties

\begin{tabular}{|c|c|c|}
\hline & Range of values & $\begin{array}{l}\text { Estimated } \\
\text { uncertainty }(1 \sigma)\end{array}$ \\
\hline Absorption length D due to light divergence & $18 \mathrm{~mm}$ & $5 \%$ \\
\hline Plug flow approximation & & $1 \%$ \\
\hline $\begin{array}{l}I_{185}, \text { (photocurrent corresponding to } 184.9 \mathrm{~nm} \\
\text { with correction for } 254 \mathrm{~nm} \text { contribution) }\end{array}$ & $0.01-1, \mathrm{nA}$ & $5 \%$ \\
\hline$\left[\mathrm{H}_{2} \mathrm{O}\right]$ & $(0.5-7) \times 10^{17}, \mathrm{~cm}^{-3}$ & $5 \%$ a) \\
\hline$\left[\mathrm{SO}_{2}\right]$ & $\left(10^{-4}-10\right) \times 10^{14}, \mathrm{~cm}^{-3}$ & $5 \%$ b) \\
\hline$C_{\mathrm{N} 2 \mathrm{O}}\left(\mathrm{NO}, f\left(\mathrm{~N}_{2} \mathrm{O}\right)\right)$ & $1100-1200, \mathrm{ppt} \mathrm{nA}^{-1}$ & $20 \%$ c) \\
\hline$K_{\mathrm{OH}}\left(\right.$ wall loss at $\left.\left[\mathrm{SO}_{2}\right]^{\mathrm{R}}=0\right)$ & $2-3.5, \mathrm{~s}^{-1}$ & $10 \%$ \\
\hline$K_{\mathrm{H} 2 \mathrm{SO} 4}$ & $1-2.5, \mathrm{~s}^{-1}$ & $10 \%$ \\
\hline Wall losses correction for $\mathrm{OH}$ & $0.87-0.93^{\mathrm{d})}$ & $10 \%$ \\
\hline$[\mathrm{OH}]^{\text {calc }}$ & & $25 \%$ \\
\hline$\left[\mathrm{H}_{2} \mathrm{SO}_{4}\right]^{\text {calc }}$ & & $35 \%$ e) \\
\hline $\mathrm{COH}_{\mathrm{OH}}$ & $(3.4-3.6) \times 10^{10}$ & $30 \%$ \\
\hline$C_{\mathrm{H} 2 \mathrm{SO} 4}$ & $(3.4-3.6) \times 10^{10}$ & $40 \%$ e) \\
\hline$C_{\mathrm{SA}}=C_{\mathrm{H} 2 \mathrm{SO} 4} / C_{\mathrm{OH}}$ & $0.9-0.95$ & $8 \%$ f) \\
\hline \multicolumn{3}{|l|}{ Resulting calibration uncertainties } \\
\hline$[\mathrm{OH}], \mathrm{cm}^{-3}$ & $2 \times 10^{5}-2 \times 10^{9}$ & $30 \%$ \\
\hline$\left[\mathrm{H}_{2} \mathrm{SO}_{4}\right], \mathrm{cm}^{-3}$ & $1 \times 10^{5}-2 \times 10^{9}$ & $32 \% \mathrm{~g})$ \\
\hline$\left[\mathrm{H}_{2} \mathrm{SO}_{4}\right] /[\mathrm{OH}]$ & $10^{-4}-10^{4}$ & $8 \%$ g) \\
\hline
\end{tabular}

a) With Michell Instruments Optidew chilled mirror hygrometer

b) Using $\mathrm{SO}_{2}$ monitor TELEDYNE T100U

c) Uncertainties of $\mathrm{NO}, f\left(\mathrm{~N}_{2} \mathrm{O}\right.$ and $\Delta \mathrm{I}^{\mathrm{NO}}$ are $10 \%, 15 \%, 10 \%$, respectively

d) At flow tube length of $5 \mathrm{~cm}$

e) Using $\mathrm{H}_{2} \mathrm{SO}_{4}{ }^{\text {calc }}$ from ( $\left.\mathrm{S} 15\right)$

f) Using the method shown in Figure $\mathrm{S} 8$

g) Using $\mathrm{C}_{\mathrm{SA}}$ 


\section{S4 Estimation of $\mathrm{H}_{2} \mathrm{SO}_{4}$ production in reactions of $\mathrm{SCIs}$ with $\mathrm{SO}_{2}$}

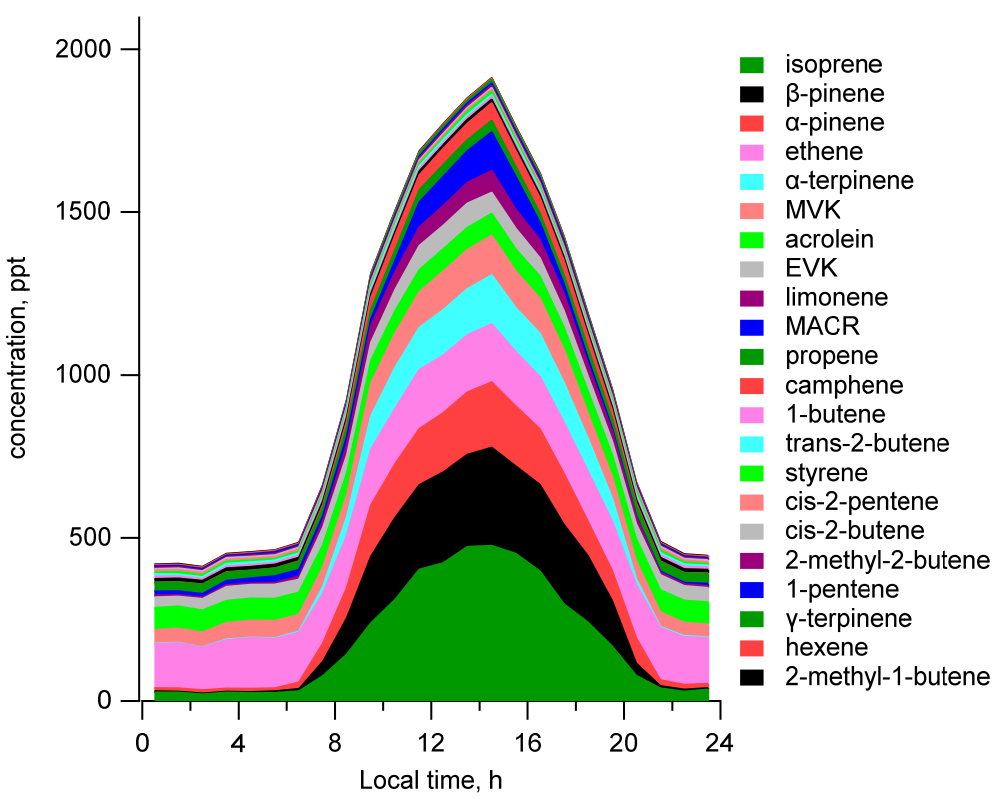

Figure S9. Median diel concentration profiles of observed unsaturated VOCs

Table S4. Measured unsaturated VOCs and the corresponding measurement techniques, VOCs $+\mathrm{O}_{3}$ reaction rate coefficients $\left(k_{\mathrm{VOC}+03}\right)$, specific yields of Criegee Intermediates $(\mathrm{CI})\left(\mathrm{Y}_{\mathrm{SCI}}\right)$ and yields of stabilized CIs (SCIs) $\left(\alpha_{\mathrm{SCI}}\right)$

\begin{tabular}{|c|c|c|c|c|c|c|c|}
\hline & VOC & Method & $\begin{array}{c}\text { Median (ppt) } \\
\text { Day }(7 \mathrm{~h}-20 \mathrm{~h}) / \\
\text { Night }(20 \mathrm{~h}-7 \mathrm{~h})\end{array}$ & $\begin{array}{c}k_{\text {voc }+03^{\text {a) }},}, 10^{-17} \\
\mathrm{~cm}^{3} \text { molecule }^{-1} \mathrm{~s}^{-1}\end{array}$ & $\begin{array}{c}\text { Yield of } \\
\text { stabilized SCI } \\
\alpha_{\mathrm{sc}} \mathrm{b}^{\mathrm{b}}\end{array}$ & & $\mathrm{SCl}$ (R1) - (R2) COO / Cl specific yield $\mathrm{Y}_{\mathrm{SCI}}{ }^{\text {b) }}$ \\
\hline 1 & Ethene & A & $167 / 153$ & 0.16 & 0.37 & 1 & $\mathrm{CH}_{2} \mathrm{OO} / 1$ \\
\hline 2 & Propene & A & $31 / 28$ & 1.0 & 0.37 & $\begin{array}{l}1 \\
2 \\
3\end{array}$ & $\begin{array}{l}\mathrm{CH}_{2} \mathrm{OO} / 0.5^{\mathrm{c}} \\
-\mathrm{CH}_{3}-\mathrm{H} / 0.4^{\mathrm{c}} \\
\left.-\mathrm{H}-\mathrm{CH}_{3} / 0.1^{\mathrm{c}}\right)\end{array}$ \\
\hline 3 & 1-Butene & A & $7 / 7$ & 1.0 & 0.4 & $\begin{array}{l}1 \\
4 \\
5\end{array}$ & $\begin{array}{l}\mathrm{CH}_{2} \mathrm{OO} / 0.5 \\
-\mathrm{CH}_{2} \mathrm{R}_{\mathrm{a}}-\mathrm{H} / 0.4 \\
-\mathrm{H}-\mathrm{CH}_{2} \mathrm{R}_{\mathrm{a}} / 0.1\end{array}$ \\
\hline 4 & $\begin{array}{l}\text { trans-2- } \\
\text { Butene }\end{array}$ & A & $7 / 7$ & 19 & 0.4 & $\begin{array}{l}2 \\
3\end{array}$ & $\begin{array}{l}-\mathrm{CH}_{3}-\mathrm{H} / 0.8 \\
-\mathrm{H}-\mathrm{CH}_{3} / 0.2\end{array}$ \\
\hline 5 & $\begin{array}{l}\text { cis-2- } \\
\text { Butene }\end{array}$ & $A^{1)}$ & 5 & 13 & 0.38 & $\begin{array}{l}2 \\
3 \\
\end{array}$ & $\begin{array}{l}-\mathrm{CH}_{3}-\mathrm{H} / 0.8 \\
-\mathrm{H}-\mathrm{CH}_{3} / 0.2 \\
\end{array}$ \\
\hline 6 & $\begin{array}{l}\text { 2-Methyl-1- } \\
\text { butene }\end{array}$ & $A^{1)}$ & 2 & $1.4^{\mathrm{d})}$ & 0.4 & $\begin{array}{l}1 \\
6 \\
7 \\
\end{array}$ & $\begin{array}{l}\mathrm{CH}_{2} \mathrm{OO} / 0.5 \\
-\mathrm{CH}_{2} \mathrm{R}_{\mathrm{a}}-\mathrm{CH}_{3} / 0.25 \\
-\mathrm{CH}_{3}-\mathrm{CH}_{2} \mathrm{R}_{\mathrm{a}} / 0.25\end{array}$ \\
\hline 7 & $\begin{array}{l}\text { 2-Methyl-2- } \\
\text { butene }\end{array}$ & $A^{3)}$ & $6 / 4$ & $40^{\text {e) }}$ & 0.4 & $\begin{array}{l}2 \\
3 \\
8 \\
\end{array}$ & $\begin{array}{l}-\mathrm{CH}_{3}-\mathrm{H} / 0.4 \\
-\mathrm{H}-\mathrm{CH}_{3} / 0.1 \\
-\mathrm{CH}_{3}-\mathrm{CH}_{3} / 0.5\end{array}$ \\
\hline 8 & $\begin{array}{l}\text { trans-2- } \\
\text { Pentene }\end{array}$ & $A^{1)}$ & 11 & $16^{d)}$ & 0.4 & $\begin{array}{l}2 \\
3 \\
4 \\
5 \\
\end{array}$ & $\begin{array}{l}-\mathrm{CH}_{3}-\mathrm{H} / 0.4 \\
-\mathrm{H}-\mathrm{CH}_{3} / 0.1 \\
-\mathrm{CH}_{2} \mathrm{R}_{\mathrm{a}}-\mathrm{H} / 0.4 \\
-\mathrm{H}-\mathrm{CH}_{2} \mathrm{R}_{\mathrm{a}} / 0.1 \\
\end{array}$ \\
\hline 9 & $\begin{array}{l}\text { cis-2- } \\
\text { Pentene }\end{array}$ & $A^{1)}$ & $6 / 6$ & $13^{d)}$ & 0.29 & $\begin{array}{l}2 \\
3 \\
4 \\
5\end{array}$ & $\begin{array}{l}-\mathrm{CH}_{3}-\mathrm{H} / 0.4 \\
-\mathrm{H}-\mathrm{CH}_{3} / 0.1 \\
-\mathrm{CH}_{2} \mathrm{R}_{\mathrm{a}}-\mathrm{H} / 0.4 \\
-\mathrm{H}-\mathrm{CH}_{2} \mathrm{R}_{\mathrm{a}} / 0.1\end{array}$ \\
\hline 10 & 1-Pentene & $A^{3)}$ & $6 / 4$ & $0.9^{d)}$ & 0.29 & $\begin{array}{l}1 \\
4 \\
5\end{array}$ & $\begin{array}{l}\mathrm{CH}_{2} \mathrm{OO} / 0.5 \\
-\mathrm{CH}_{2} \mathrm{R}_{\mathrm{a}}-\mathrm{H} / 0.4 \\
-\mathrm{H}-\mathrm{CH}_{2} \mathrm{R}_{\mathrm{a}} / 0.1\end{array}$ \\
\hline 11 & 1-Hexene & $\mathrm{B}^{1)}$ & $4 / 4$ & $1.0^{\mathrm{d})}$ & 0.4 & $\begin{array}{l}1 \\
4 \\
5\end{array}$ & $\begin{array}{l}\mathrm{CH}_{2} \mathrm{OO} / 0.5 \\
\left.-\mathrm{CH}_{2} \mathrm{R}_{\mathrm{a}}-\mathrm{H} / 0.4 \mathrm{~g}\right) \\
\left.-\mathrm{H}-\mathrm{CH}_{2} \mathrm{R}_{\mathrm{a}} / 0.1 \mathrm{~g}\right)\end{array}$ \\
\hline
\end{tabular}




\begin{tabular}{|c|c|c|c|c|c|c|c|}
\hline 12 & Isoprene & $C, D$ & $355 / 32$ & 1.3 & $\begin{array}{l}0.95^{f)} \\
0.34^{f)} \\
0.54^{f)} \\
0.37^{f)} \\
0.2^{f)}\end{array}$ & $\begin{array}{c}1 \\
9 \\
10 \\
11 \\
12\end{array}$ & $\begin{array}{l}\mathrm{CH}_{2} \mathrm{OO} / 0.33^{\mathrm{fl}} \\
\mathrm{Z}-\left(\mathrm{CH}=\mathrm{CH}_{2}\right)\left(\mathrm{CH}_{3}\right) \mathrm{COO} / 0.21^{\mathrm{ff}}(\mathrm{MVK} \text { oxide }) \\
\mathrm{E}-\left(\mathrm{CH}=\mathrm{CH}_{2}\right)\left(\mathrm{CH}_{3}\right) \mathrm{COO} / 0.26^{\mathrm{f})} \\
\mathrm{Z}-\left(\mathrm{C}\left(\mathrm{CH}_{3}\right)=\mathrm{CH}_{2}\right) \mathrm{CHOO} / 0.02^{\mathrm{ff}} \text { (MACR-oxide) } \\
\mathrm{E}-\left(\mathrm{C}\left(\mathrm{CH}_{3}\right)=\mathrm{CH}_{2}\right) \mathrm{CHOO} / 0.2^{\mathrm{f})}\end{array}$ \\
\hline 13 & $\underline{\alpha-p i n e n e}$ & B & $162 / 13$ & 9.6 & 0.15 & $\begin{array}{l}13 \\
14 \\
15 \\
16\end{array}$ & $\begin{array}{l}\text { Z-pinonaldehyde-K-oxide / } 0.25 \\
\text { E-pinonaldehyde-K-oxide / } 0.25 \\
\text { Z-pinonaldehyde-A-oxide / } 0.25 \\
\text { E-pinonaldehyde-A-oxide / } 0.25\end{array}$ \\
\hline 14 & $\beta$-pinene & B & $247 / 6$ & 1.9 & 0.5 & $\begin{array}{c}1 \\
17 \\
18\end{array}$ & $\begin{array}{l}\mathrm{CH}_{2} \mathrm{OO} / 0.1 \\
\text { Z-Nopinone oxide / } 0.77 \\
\text { E-Nopinone oxide / } 0.13\end{array}$ \\
\hline 15 & Camphene & B & $44 / 1$ & 0.05 & $0.5^{\text {h) }}$ & $\begin{array}{c}1 \\
19 \\
20\end{array}$ & $\begin{array}{l}\mathrm{CH}_{2} \mathrm{OO} / 0.5^{\mathrm{g})} \\
-\mathrm{CRaRbRc}-\mathrm{CHRdRe} / 0.25^{\mathrm{g})} \\
\left.-\mathrm{CHRdRe}-\mathrm{CRaRbRc} / 0.25^{\mathrm{g}}\right)\end{array}$ \\
\hline 16 & Limonene & B & $53 / 7$ & 22 & 0.27 & $\begin{array}{c}1 \\
4 \\
5 \\
6 \\
7 \\
21 \\
22\end{array}$ & $\begin{array}{l}\mathrm{CH}_{2} \mathrm{OO} / 0.11 \\
-\mathrm{CH}_{2} \mathrm{R}_{\mathrm{a}}-\mathrm{H} / 0.31 \\
-\mathrm{H}-\mathrm{CH}_{2} \mathrm{R}_{\mathrm{a}} / 0.08 \\
-\mathrm{CH}_{2} \mathrm{Ra}_{\mathrm{a}}-\mathrm{CH}_{3} / 0.195 \\
-\mathrm{CH}_{3}-\mathrm{CH}_{2} \mathrm{Ra}_{\mathrm{a}} / 0.195 \\
-\mathrm{CHR}_{\mathrm{a}} \mathrm{R}_{\mathrm{b}}-\mathrm{CH}_{3} / 0.055 \\
-\mathrm{CH}_{3}-\mathrm{CHR}_{\mathrm{a}} \mathrm{R}_{\mathrm{b}} / 0.055\end{array}$ \\
\hline 17 & $\gamma$-terpinene & B & $11 / 0$ & 16 & 0.15 & $\begin{array}{c}5 \\
7 \\
23 \\
24 \\
25 \\
26\end{array}$ & $\begin{array}{l}-\mathrm{H}-\mathrm{CH}_{2} \mathrm{R}_{\mathrm{a}} / 0.135+0.115 \\
-\mathrm{CH}_{3}-\mathrm{CH}_{2} \mathrm{R}_{\mathrm{a}} / 0.115 \\
-\mathrm{CH}_{2}-\mathrm{CR}_{3}=\mathrm{CR}_{4} \mathrm{R}_{5}-\mathrm{H} / 0.135+0.115 \\
-\mathrm{CH}_{2}-\mathrm{CR}_{3}=\mathrm{CR}_{4} \mathrm{R}_{5}-\mathrm{CH}_{3} / 0.115 \\
-\mathrm{CH}_{2}-\mathrm{CR}_{3}=\mathrm{CR}_{4} \mathrm{R}_{5}-\mathrm{CHR}_{\mathrm{a}} \mathrm{R}_{\mathrm{b}} / 0.135 \\
-\mathrm{CHR}_{\mathrm{a}} \mathrm{R}_{\mathrm{b}}-\mathrm{CH}_{2} \mathrm{R}_{\mathrm{a}} / 0.135\end{array}$ \\
\hline 18 & $\begin{array}{l}\alpha- \\
\text { terpinene }\end{array}$ & B & $124 / 3$ & 1900 & 0.15 & $\begin{array}{c}6 \\
7 \\
26 \\
27 \\
28 \\
29\end{array}$ & $\begin{array}{l}-\mathrm{CH}_{2} \mathrm{R}_{\mathrm{a}}-\mathrm{CH}_{3} / 0.125 \\
-\mathrm{CH}_{3}-\mathrm{CH}_{2} \mathrm{R}_{\mathrm{a}} / 0.125 \\
-\mathrm{CHR}_{\mathrm{a}} \mathrm{R}_{\mathrm{b}}-\mathrm{CH}_{2} \mathrm{R}_{\mathrm{a}} / 0.125 \\
-\mathrm{CH}_{2} \mathrm{R}_{\mathrm{a}}-\mathrm{CHR}_{\mathrm{a}} \mathrm{R}_{\mathrm{b}} / 0.125 \\
-\left(\mathrm{CR}_{3}=\mathrm{CR}_{4} \mathrm{CH}_{3}\right)-\mathrm{H} / 0.25 \\
-\mathrm{H}-\left(\mathrm{CR}_{3}=\mathrm{CR}_{4} \mathrm{CH}_{3}\right) / 0.25\end{array}$ \\
\hline 19 & $\begin{array}{l}\frac{\text { Methyl }}{\text { vinyl }} \\
\frac{\text { ketone }}{\text { (MVK) }}\end{array}$ & $C \& D^{2)}$ & $102 / 45$ & 0.52 & 0.4 & $\begin{array}{c}1 \\
30 \\
31\end{array}$ & $\begin{array}{l}\mathrm{CH}_{2} \mathrm{OO} / 0.5 \\
-\mathrm{C}(\mathrm{O}) \mathrm{Ra}-\mathrm{H} / 0.25 \\
-\mathrm{H}-\mathrm{C}(\mathrm{O}) \mathrm{R}_{3} / 0.25\end{array}$ \\
\hline 20 & $\begin{array}{l}\text { Ethyl vinyl } \\
\text { ketone } \\
\text { (EVK) }\end{array}$ & C & $62 / 40$ & $0.6^{\mathrm{g})}$ & 0.4 & $\begin{array}{c}1 \\
30 \\
31\end{array}$ & $\begin{array}{l}\mathrm{CH}_{2} \mathrm{OO} / 0.5 \\
-\mathrm{C}(\mathrm{O}) \mathrm{Ra}-\mathrm{H} / 0.25 \\
-\mathrm{H}-\mathrm{C}(\mathrm{O}) \mathrm{R}_{3} / 0.25\end{array}$ \\
\hline 21 & $\frac{\text { Methacrole }}{\text { in (MACR) }}$ & $C \& D^{2)}$ & $48 / 5$ & 0.12 & 0.4 & $\begin{array}{c}1 \\
32 \\
33\end{array}$ & $\begin{array}{l}\mathrm{CH}_{2} \mathrm{OO} / 0.5 \\
-\mathrm{C}(\mathrm{O}) \mathrm{H}-\mathrm{CH}_{3} / 0.25 \\
-\mathrm{CH}_{3}-\mathrm{C}(\mathrm{O}) \mathrm{R}_{3} / 0.25\end{array}$ \\
\hline 22 & $\begin{array}{l}\text { Acrolein } \\
\text { (Propenal) }\end{array}$ & $E^{1)}$ & 68 & $0.014^{\mathrm{g})}$ & 0.4 & $\begin{array}{c}1 \\
34 \\
31\end{array}$ & $\begin{array}{l}\mathrm{CH}_{2} \mathrm{OO} / 0.5 \\
-\mathrm{C}(\mathrm{O}) \mathrm{H}-\mathrm{H} / 0.25 \\
-\mathrm{H}-\mathrm{C}(\mathrm{O}) \mathrm{R}_{3} / 0.25\end{array}$ \\
\hline 23 & Styrene & $B \& A^{4)}$ & $8 / 6$ & $1.4^{\text {h) }}$ & 0.4 & $\begin{array}{c}1 \\
35 \\
36\end{array}$ & $\begin{array}{l}\mathrm{CH}_{2} \mathrm{OO} / 0.5 \\
-\mathrm{CRaRbRc}-\mathrm{H} / 0.25 \\
-\mathrm{H}-\mathrm{CRaRbRc} / 0.25\end{array}$ \\
\hline
\end{tabular}

A) Online GC-FID-FID; time resolution $90 \mathrm{~min}$; LOD range 10-100ppt; uncertainty range 5-23\%

B) Offline solid adsorption + GC FID; time resolution 180 min; LOD 5ppt; uncertainty range $25 \%$

C) PTR MS; time resolution 10 min; LOD range 7-500ppt; uncertainty range 6-23\%

D) Online GC-FID-MS; time resolution 90 min; LOD range 5-100ppt; uncertainty range 5-14\%

E) DNPH-HPLC; time resolution $180 \mathrm{~min}$; LOD range 6-40ppt; uncertainty range $25 \%$

1) Averaged value was used

2) The sum of MVK and MACR measured by PTRMS the MVK measurements by online GC-FID-MS

3) From the sum of 1-Pentene and 2-Methyl-2-butene (taken 1 to 1)

4) combined data from GC-FID and SA-GC-FID

a) All the rate constants are from Atkinson et al. (2006) and IUPAC (2020), except indicated otherwise

b) SCIs naming convention and $\mathrm{Y}_{\mathrm{SCI}}$ are from Vereecken et al. (2017) and references therein, except indicated otherwise

c) (Novelli et al., 2014)

d) (Avzianova and Ariya, 2002)

e) (Witter et al., 2002)

f) (Zhang et al., 2002)

g) (Grosjean et al., 1993)

h) (Le Person et al., 2008) 
Table S5. SCIs derived from observed unsaturated VOCs, their precursor VOCs and their rate coefficients for thermal decomposition and reactions with $\mathrm{H}_{2} \mathrm{O}$ and $\left.\left(\mathrm{H}_{2} \mathrm{O}\right)_{2}{ }^{*}\right)$

\begin{tabular}{|c|c|c|c|c|c|c|}
\hline & $\mathrm{SCl}$ & $\begin{array}{l}\left.K,{ }^{A}\right) \\
s^{-1}\end{array}$ & $\begin{array}{l}k_{\mathrm{H} 2 \mathrm{O}^{-}}{ }^{\text {A) B) }} \\
\mathrm{cm}^{-3} \mathrm{~s}^{-1}\end{array}$ & $\begin{array}{l}k_{(\mathrm{H} 20) 2,2}{ }^{\text {A) B) }} \\
\mathrm{cm}^{-3} \mathrm{~s}^{-1}\end{array}$ & $\begin{array}{l}k_{\mathrm{SO} 2} \\
\mathrm{~cm}^{-3} \mathrm{~s}^{-1}\end{array}$ & Precursor \\
\hline 1 & $\mathrm{CH}_{2} \mathrm{OO}$ & 0.3 & $\begin{array}{l}8.7 \times 10^{-16} \\
(435)\end{array}$ & $\begin{array}{c}1.4 \times 10^{-12} \\
(700)\end{array}$ & $3.7 \times 10^{-11}$ & $\begin{array}{l}\text { Ethene, propene, 1-Butene, 2-Methyl-1- } \\
\text { butene, 1-pentene, 1-hexene, isoprene, } \\
\beta \text {-pinene, camphene, limonene, MVK, } \\
\text { EVK, MACR, acrolein, styrene }\end{array}$ \\
\hline 2 & $\mathrm{Z}-\left(\mathrm{CH}_{3}\right) \mathrm{CHOO}$ & 136 & $\begin{array}{c}6.7 \times 10^{-19} \\
(0.3)\end{array}$ & $\begin{array}{c}2.3 \times 10^{-14} \\
(12)\end{array}$ & $2.7 \times 10^{-11}$ & $\begin{array}{l}\text { Propene, trans-2-butene, cis-2-butene, } \\
\text { 2-Methyl-2-butene, trans-2-pentene, } \\
\text { cis-2-pentene }\end{array}$ \\
\hline 3 & $\mathrm{E}-\left(\mathrm{CH}_{3}\right) \mathrm{CHOO}$ & 53 & $\begin{array}{l}2.3 \times 10^{-14} \\
\left(1.2 \times 10^{4}\right)\end{array}$ & $\begin{array}{l}2.7 \times 10^{-11} \\
\left(1.4 \times 10^{4}\right)\end{array}$ & $1.4 \times 10^{-10}$ & $\begin{array}{l}\text { Propene, trans-2-butene, cis-2-butene, } \\
\text { 2-Methyl-2-butene, trans-2-pentene, } \\
\text { cis-2-pentene }\end{array}$ \\
\hline 4 & $\mathrm{Z}-\left(\mathrm{CH}_{2} \mathrm{R}_{\mathrm{a}}\right) \mathrm{CHOO}$ & 205 & $\begin{array}{l}1.5 \times 10^{-18} \\
(1)\end{array}$ & $\begin{array}{l}4.3 \times 10^{-15} \\
(2)\end{array}$ & $2.7 \times 10^{-11}$ & $\begin{array}{llr}\text { 1-butene, } & \text { trans-2-pentene, } & \text { cis-2- } \\
\text { pentene, } & 1 \text {-pentene, } & \text { 1-hexene, } \\
\text { limonene } & \end{array}$ \\
\hline 5 & $\mathrm{E}-\left(\mathrm{CH}_{2} \mathrm{R}_{\mathrm{a}}\right) \mathrm{CHOO}$ & 74 & $\begin{array}{c}1.6 \times 10^{-14} \\
\left(8 \times 10^{3}\right)\end{array}$ & $\begin{array}{l}1.7 \times 10^{-11} \\
\left(8.5 \times 10^{3}\right)\end{array}$ & $1.4 \times 10^{-10}$ & $\begin{array}{llr}\text { 1-butene, } & \text { trans-2-pentene, cis-2- } \\
\text { pentene, } 1 \text {-pentene, } 1 \text {-hexene, } \\
\text { limonene, } \gamma \text {-terpinene }\end{array}$ \\
\hline 6 & $\mathrm{Z}-\left(\mathrm{CH}_{2} \mathrm{R}_{\mathrm{a}}\right)\left(\mathrm{CH}_{3}\right) \mathrm{COO}$ & 689 & $\begin{array}{c}1.5 \times 10^{-17} \\
(8)\end{array}$ & $\begin{array}{c}3.2 \times 10^{-14} \\
(16)\end{array}$ & $1.6 \times 10^{-10}$ & $\begin{array}{l}\text { 2-methyl-1-butene, limonene, } \alpha \text { - } \\
\text { terpinene }\end{array}$ \\
\hline 7 & $\mathrm{E}-\left(\mathrm{CH}_{2} \mathrm{R}_{\mathrm{a}}\right)\left(\mathrm{CH}_{3}\right) \mathrm{COO}$ & 433 & $\begin{array}{l}9.0 \times 10^{-18} \\
(5)\end{array}$ & $\begin{array}{l}2.1 \times 10^{-14} \\
(11)\end{array}$ & $1.6 \times 10^{-10}$ & $\begin{array}{l}\text { 2-methyl-1-butene, limonene, } \\
\text { terpinene, } \alpha \text {-terpinene }\end{array}$ \\
\hline 8 & $\left(\mathrm{CH}_{3}\right)_{2} \mathrm{COO}$ & 478 & $\begin{array}{l}7.5 \times 10^{-18} \\
(4)\end{array}$ & $\begin{array}{l}1.8 \times 10^{-14} \\
(9)\end{array}$ & $1.6 \times 10^{-10}$ & 2-methyl-2-butene \\
\hline 9 & Z-MVK-oxide & $\begin{array}{l}1.3 \times 10^{4} \\
2140^{\text {al }}\end{array}$ & $\begin{array}{l}1.8 \times 10^{-18} \\
(1)\end{array}$ & $\begin{array}{l}4.8 \times 10^{-15} \\
(2)\end{array}$ & $1.6 \times 10^{-10}$ & isoprene \\
\hline 10 & E-MVK-oxide & $\begin{array}{c}33^{\text {a) b) }} \\
70^{\text {c) }} \\
\end{array}$ & $\begin{array}{c}8.1 \times 10^{-20} \\
(0.04)\end{array}$ & $\begin{array}{c}3.1 \times 10^{-16} \\
(0.2)\end{array}$ & $4.2 \times 10^{-11 b)}$ & isoprene \\
\hline 11 & Z-MACR- oxide & $1.4 \times 10^{4}$ & $\begin{array}{c}1.2 \times 10^{-19} \\
(0.1) \\
\end{array}$ & $\begin{array}{c}4.3 \times 10^{-16} \\
(0.2) \\
\end{array}$ & $1.6 \times 10^{-10}$ & isoprene \\
\hline 12 & E-MACR- oxide & 30 & $\begin{array}{c}1.4 \times 10^{-16} \\
(70) \\
(9 \pm 5) \times 10^{-17 d)}\end{array}$ & $\begin{array}{l}2.7 \times 10^{-13} \\
(135)\end{array}$ & $\begin{array}{l}1.6 \times 10^{-10} \\
1.5 \times 10^{-10 d)}\end{array}$ & isoprene \\
\hline 13 & Z-pinonaldehyde-K- oxide & 60 & $\begin{array}{c}2.4 \times 10^{-19} \\
(0.1) \\
\end{array}$ & $\begin{array}{c}8.9 \times 10^{-16} \\
(0.4)\end{array}$ & $1.6 \times 10^{-10}$ & $\alpha$-pinene \\
\hline 14 & E-pinonaldehyde-K- oxide & 250 & $\begin{array}{c}9.8 \times 10^{-18} \\
(5)\end{array}$ & $\begin{array}{c}3.2 \times 10^{-15} \\
(2)\end{array}$ & $1.6 \times 10^{-10}$ & $\alpha$-pinene \\
\hline 15 & Z-pinonaldehyde-A-oxide & 634 & $\begin{array}{c}1.3 \times 10^{-18} \\
(1)\end{array}$ & $\begin{array}{c}3.6 \times 10^{-15} \\
(2)\end{array}$ & $2.7 \times 10^{-11}$ & $\alpha$-pinene \\
\hline 16 & E-pinonaldehyde-A-oxide & 62 & $\begin{array}{l}1.6 \times 10^{-14} \\
\left(8 \times 10^{3}\right)\end{array}$ & $\begin{array}{l}1.7 \times 10^{-11} \\
\left(8.5 \times 10^{3}\right)\end{array}$ & $1.4 \times 10^{-10}$ & $\alpha$-pinene \\
\hline 17 & Z-Nopinone oxide & 2 & $\begin{array}{l}4.2 \times 10^{-16} \\
(210)\end{array}$ & $\begin{array}{c}6.0 \times 10^{-13} \\
(300)\end{array}$ & $4.0 \times 10^{-11}$ & $\beta$-pinene \\
\hline 18 & E-Nopinone oxide & 375 & $\begin{array}{c}1.7 \times 10^{-18} \\
(1)\end{array}$ & $\begin{array}{l}3.7 \times 10^{-15} \\
(2)\end{array}$ & $1.6 \times 10^{-10}$ & $\beta$-pinene \\
\hline 19 & Z-(CRaRbRc)(CHRdRe)COO & 1.1 & $\begin{array}{c}2.4 \times 10^{-17} \\
(12)\end{array}$ & $\begin{array}{c}4.5 \times 10^{-14} \\
(23) \\
\end{array}$ & $1.6 \times 10^{-10}$ & Camphene \\
\hline 20 & $\mathrm{E}-(\mathrm{CRaRbRc})(\mathrm{CHRdRe}) \mathrm{COO}$ & 1 & $\begin{array}{c}3.2 \times 10^{-17} \\
(16)\end{array}$ & $\begin{array}{c}5.9 \times 10^{-14} \\
(30)\end{array}$ & $1.6 \times 10^{-10}$ & Camphene \\
\hline 21 & $\mathrm{Z}-\left(\mathrm{CHR}_{\mathrm{a}} \mathrm{R}_{\mathrm{b}}\right)\left(\mathrm{CH}_{3}\right) \mathrm{COO}$ & 14 & $\begin{array}{l}9.8 \times 10^{-18} \\
(5)\end{array}$ & $\begin{array}{c}1.9 \times 10^{-14} \\
(\mathbf{1 0})\end{array}$ & $1.6 \times 10^{-10}$ & Limonene \\
\hline 22 & $\mathrm{E}-\left(\mathrm{CHR}_{\mathrm{a}} \mathrm{R}_{\mathrm{b}}\right)\left(\mathrm{CH}_{3}\right) \mathrm{COO}$ & 611 & $\begin{array}{c}4.3 \times 10^{-18} \\
(2)\end{array}$ & $\begin{array}{c}1.1 \times 10^{-14} \\
(6)\end{array}$ & $1.6 \times 10^{-10}$ & Limonene \\
\hline 23 & $\mathrm{Z}-\left(\mathrm{CH}_{2}-\mathrm{CR}_{3}=\mathrm{CR}_{4} \mathrm{R}_{5}\right) \mathrm{CHOO}$ & 4180 & $\begin{array}{l}1.5 \times 10^{-18} \\
(1)\end{array}$ & $\begin{array}{l}3.9 \times 10^{-15} \\
(2)\end{array}$ & $2.7 \times 10^{-11}$ & $\gamma$-terpinene \\
\hline 24 & $\mathrm{Z}-\left(\mathrm{CH}_{2}-\mathrm{CR}_{3}=\mathrm{CR}_{4} \mathrm{R}_{5}\right)\left(\mathrm{CH}_{3}\right) \mathrm{COO}$ & 1400 & $\begin{array}{l}4.1 \times 10^{-18} \\
(2)\end{array}$ & $\begin{array}{l}2.9 \times 10^{-14} \\
(15)\end{array}$ & $1.6 \times 10^{-10}$ & $\gamma$-terpinene \\
\hline 25 & $\begin{array}{l}\mathrm{Z}-\left(\mathrm{CH}_{2^{-}}\right. \\
\left.\mathrm{CR}_{3}=\mathrm{CR}_{4} \mathrm{R}_{5}\right)\left(\mathrm{CHR}_{\mathrm{a}} \mathrm{R}_{\mathrm{b}}\right) \mathrm{COO}\end{array}$ & 5250 & $\begin{array}{c}3.4 \times 10^{-17} \\
(17)\end{array}$ & $\begin{array}{c}6.1 \times 10^{-14} \\
(31)\end{array}$ & $1.6 \times 10^{-10}$ & $\gamma$-terpinene \\
\hline 26 & $\mathrm{Z}-\left(\mathrm{CHR}_{\mathrm{a}} \mathrm{R}_{\mathrm{b}}\right)\left(\mathrm{CH}_{2} \mathrm{R}_{\mathrm{a}}\right) \mathrm{COO}$ & 13 & $\begin{array}{c}1.3 \times 10^{-17} \\
(7)\end{array}$ & $\begin{array}{c}2.8 \times 10^{-14} \\
(14)\end{array}$ & $1.6 \times 10^{-10}$ & $\gamma$-terpinene, $\alpha$-terpinene \\
\hline 27 & $\mathrm{E}-\left(\mathrm{CH}_{2} \mathrm{R}_{\mathrm{a}}\right)\left(\mathrm{CHR}_{\mathrm{a}} \mathrm{R}_{\mathrm{b}}\right) \mathrm{COO}$ & 257 & $\begin{array}{l}3.5 \times 10^{-17} \\
(18)\end{array}$ & $\begin{array}{c}6.8 \times 10^{-14} \\
(34)\end{array}$ & $1.6 \times 10^{-10}$ & $\alpha$-terpinene \\
\hline 28 & $\mathrm{Z}-\left(\mathrm{CR}_{3}=\mathrm{CR}_{4} \mathrm{CH}_{3}\right) \mathrm{CHOO}$ & $4.8 \times 10^{6}$ & $\begin{array}{c}1.2 \times 10^{-19} \\
(0.1)\end{array}$ & $\begin{array}{c}4.3 \times 10^{-16} \\
(0.2) \\
\end{array}$ & $2.7 \times 10^{-11}$ & $\alpha$-terpinene \\
\hline
\end{tabular}




\begin{tabular}{|l|l|c|c|c|l|l|}
\hline 29 & $\mathrm{E}-\left(\mathrm{CR}_{3}=\mathrm{CR}_{4} \mathrm{CH}_{3}\right) \mathrm{CHOO}$ & 30 & $\begin{array}{c}1.4 \times 10^{-16} \\
(\mathbf{7 0})\end{array}$ & $\begin{array}{c}2.7 \times 10^{-13} \\
(\mathbf{1 3 5})\end{array}$ & $1.4 \times 10^{-10}$ & a-terpinene \\
\hline 30 & $\mathrm{Z}-\left(\mathrm{C}(\mathrm{O}) \mathrm{R}_{\mathrm{a}}\right) \mathrm{CHOO}$ & 20 & $\begin{array}{c}3.7 \times 10^{-15} \\
(\mathbf{1 8 5 0})\end{array}$ & $\begin{array}{c}4.4 \times 10^{-12} \\
(\mathbf{2 2 0 0})\end{array}$ & $2.7 \times 10^{-11}$ & $\mathrm{MVK}, \mathrm{EVK}$ \\
\hline 31 & $\mathrm{E}-\left(\mathrm{C}(\mathrm{O}) \mathrm{R}_{3}\right) \mathrm{CHOO}$ & $\mathbf{7 . 1 \times 1 0 ^ { 4 }}$ & $\begin{array}{c}1.4 \times 10^{-14} \\
\left(7 \times 10^{3}\right)\end{array}$ & $\begin{array}{c}1.5 \times 10^{-11} \\
\left(7.5 \times 10^{3}\right)\end{array}$ & $1.6 \times 10^{-10}$ & MACR \\
\hline 32 & $\mathrm{Z}-(\mathrm{C}(\mathrm{O}) \mathrm{H})\left(\mathrm{CH}_{3}\right) \mathrm{COO}$ & $\mathbf{3 . 8}$ & $\begin{array}{c}9.8 \times 10^{-21} \\
(0.005)\end{array}$ & $\begin{array}{c}4.4 \times 10^{-17} \\
(0.02)\end{array}$ & $1.6 \times 10^{-10}$ & MACR \\
\hline 33 & $\mathrm{E}-\left(\mathrm{C}(\mathrm{O}) \mathrm{R}_{3}\right)\left(\mathrm{CH}_{3}\right) \mathrm{COO}$ & 144 & $\begin{array}{c}7.7 \times 10^{-16} \\
(\mathbf{3 8 5})\end{array}$ & $\begin{array}{c}1.1 \times 10^{-12} \\
(\mathbf{5 5 0})\end{array}$ & $2.7 \times 10^{-11}$ & Acrolein \\
\hline 34 & $\mathrm{Z}-(\mathrm{C}(\mathrm{O}) \mathrm{H}) \mathrm{CHOO}$ & 0.01 & $\begin{array}{c}1.0 \times 10^{-18} \\
(\mathbf{1})\end{array}$ & $\begin{array}{c}2.8 \times 10^{-15} \\
(\mathbf{1})\end{array}$ & $2.7 \times 10^{-11}$ & Styrene \\
\hline 35 & $\mathrm{Z}-\left(\mathrm{CR} \mathrm{R}_{\mathrm{b}} \mathrm{R}_{c}\right) \mathrm{CHOO}$ & 111 & $\begin{array}{c}4.5 \times 10^{-14} \\
\left(\mathbf{2 . 3 \times 1 0 ^ { 4 }}\right)\end{array}$ & $\begin{array}{c}4.7 \times 10^{-11} \\
\left(\mathbf{2 . 3 \times 1 0 ^ { 4 }}\right)\end{array}$ & $1.4 \times 10^{-10}$ & Styrene \\
\hline 36 & $\mathrm{E}-\left(\mathrm{CR} \mathrm{R}_{\mathrm{b}} \mathrm{R}_{c}\right) \mathrm{CHOO}$ & & & \\
\hline
\end{tabular}

*) SCIs naming convention and rate coefficients are from Vereecken et al. (2017) recommendations based on available measurements or theoretically derived SARs, except when otherwise noted.

A) In bold are presented the major loss pathways.

B) In parenthesis are presented the corresponding loss rate in $\mathrm{s}^{-1}$ at median during $\left[\mathrm{H}_{2} \mathrm{O}\right]$ and $\left[\left(\mathrm{H}_{2} \mathrm{O}\right)_{2}\right]$ ChArMEx.

a) (Barber et al., 2018)

b) (Caravan et al., 2020)

c) (Lin et al., 2020)

d) (Lin et al. 2021)
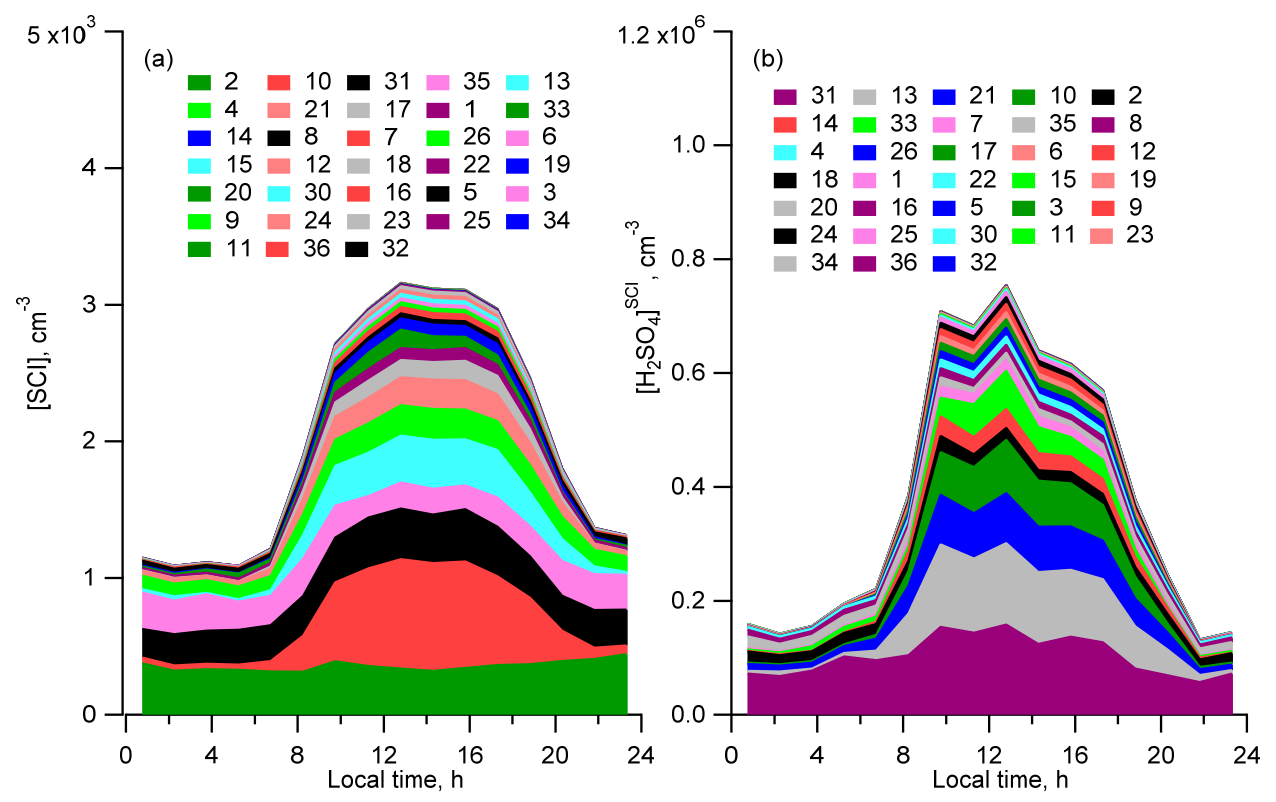

Figure S10. Calculated median diel concentration profiles of SCIs (a) produced by ozonolysis of measured unsaturated VOCs and of $\mathrm{H}_{2} \mathrm{SO}_{4}{ }^{\mathrm{SCI}}$ (b) produced by these SCIs in reaction with $\mathrm{SO}_{2}$. The numbers correspond to the SCIs listed in Tables S4 and S5. 


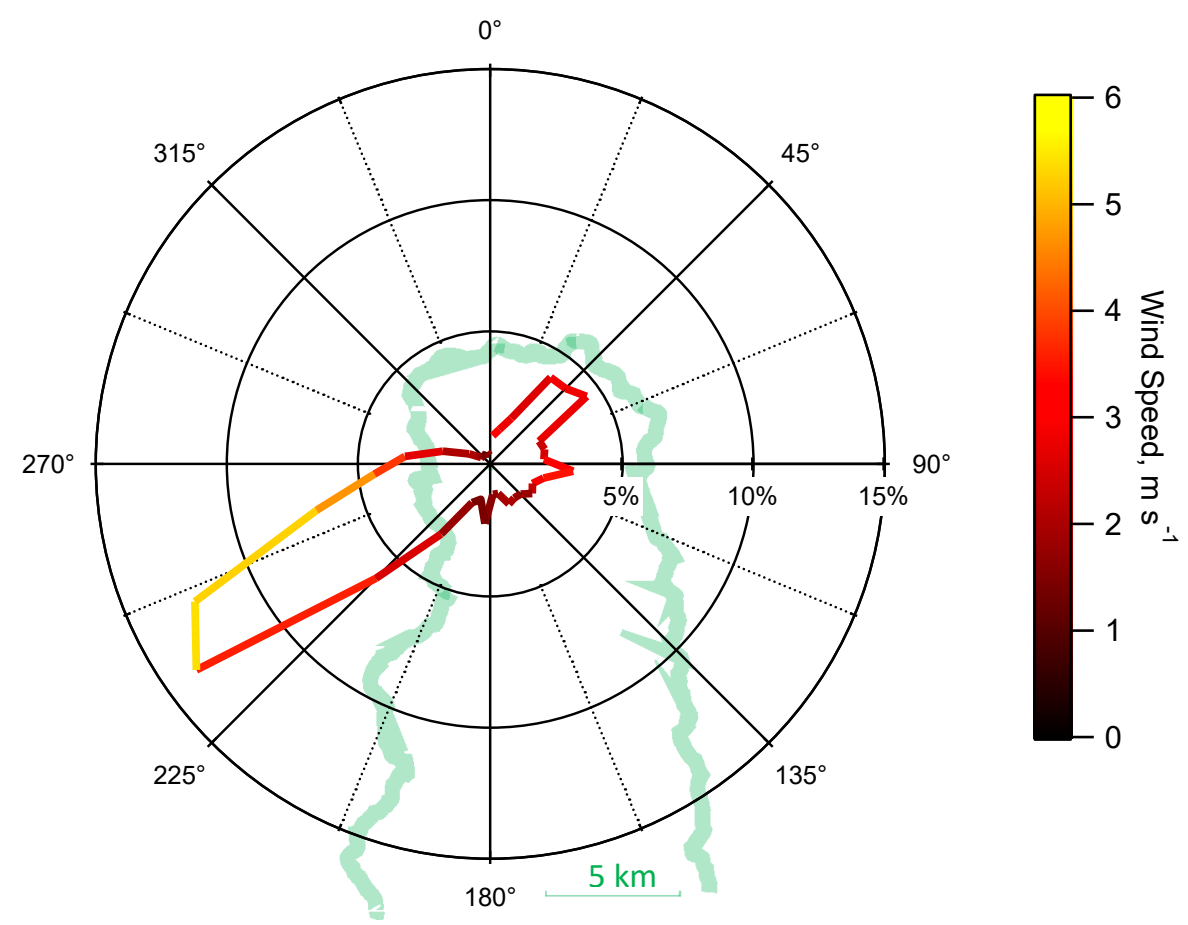

Figure S11. Wind direction probability centered at the Ersa measurements site and color coded median wind speed. Green curve represents the Cap Corse coastline

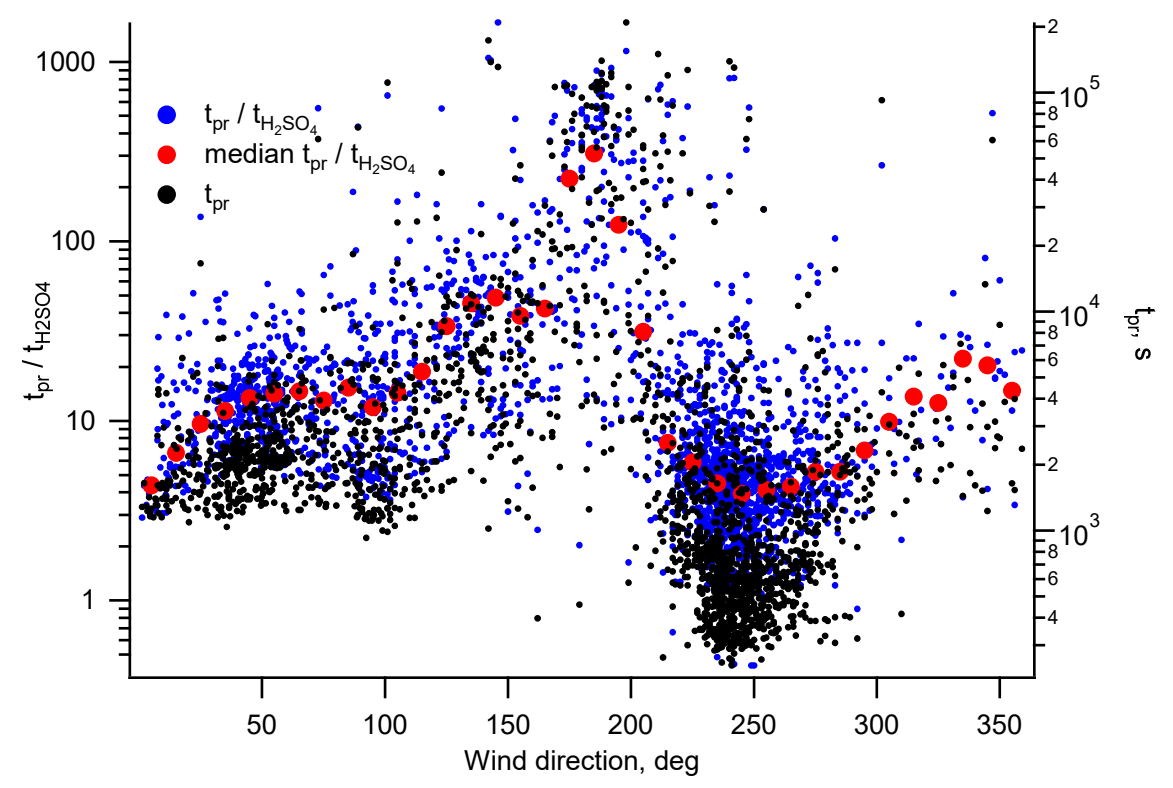

Figure S12. Ratio of air mass presence time over the land to $\mathrm{H}_{2} \mathrm{SO}_{4}$ lifetime, $t_{p r} / t_{\mathrm{H} 2 \mathrm{SO} 4}$, (blue points) and the presence time $t_{p r}$ (black points) as functions of the wind direction. Red points - median values of the ratios of $t_{p r} / t_{\mathrm{H} 2 \mathrm{SO} 4}$. 


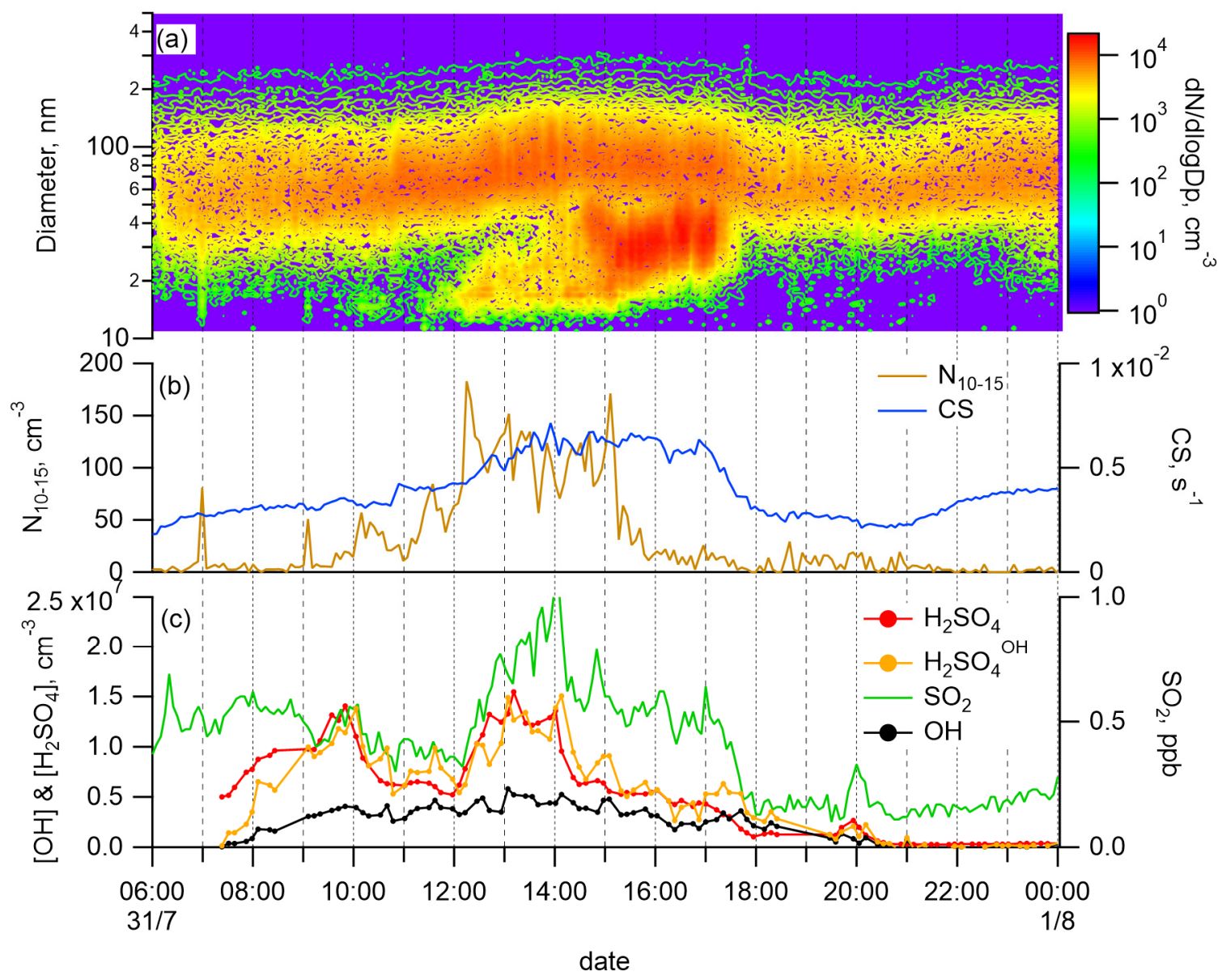

Figure S13. Example of new particles formation event (NPF) observed on 31 of July at Ersa station. (a) Time evolution of particle size distribution measured with SMPS. (b) Time profiles of the condensation sink (CS) and of the number concentration of 10-15 nm particles $\left(\mathrm{N}_{10-15}\right)$. (c) Concentration time profiles of measured $\mathrm{OH}$ radicals, $\mathrm{H}_{2} \mathrm{SO}_{4}, \mathrm{SO}_{2}$ and calculated $\mathrm{H}_{2} \mathrm{SO}_{4}{ }^{\mathrm{OH}}$, the sulfuric acid produced via $\mathrm{OH}+\mathrm{SO}_{2}$. 


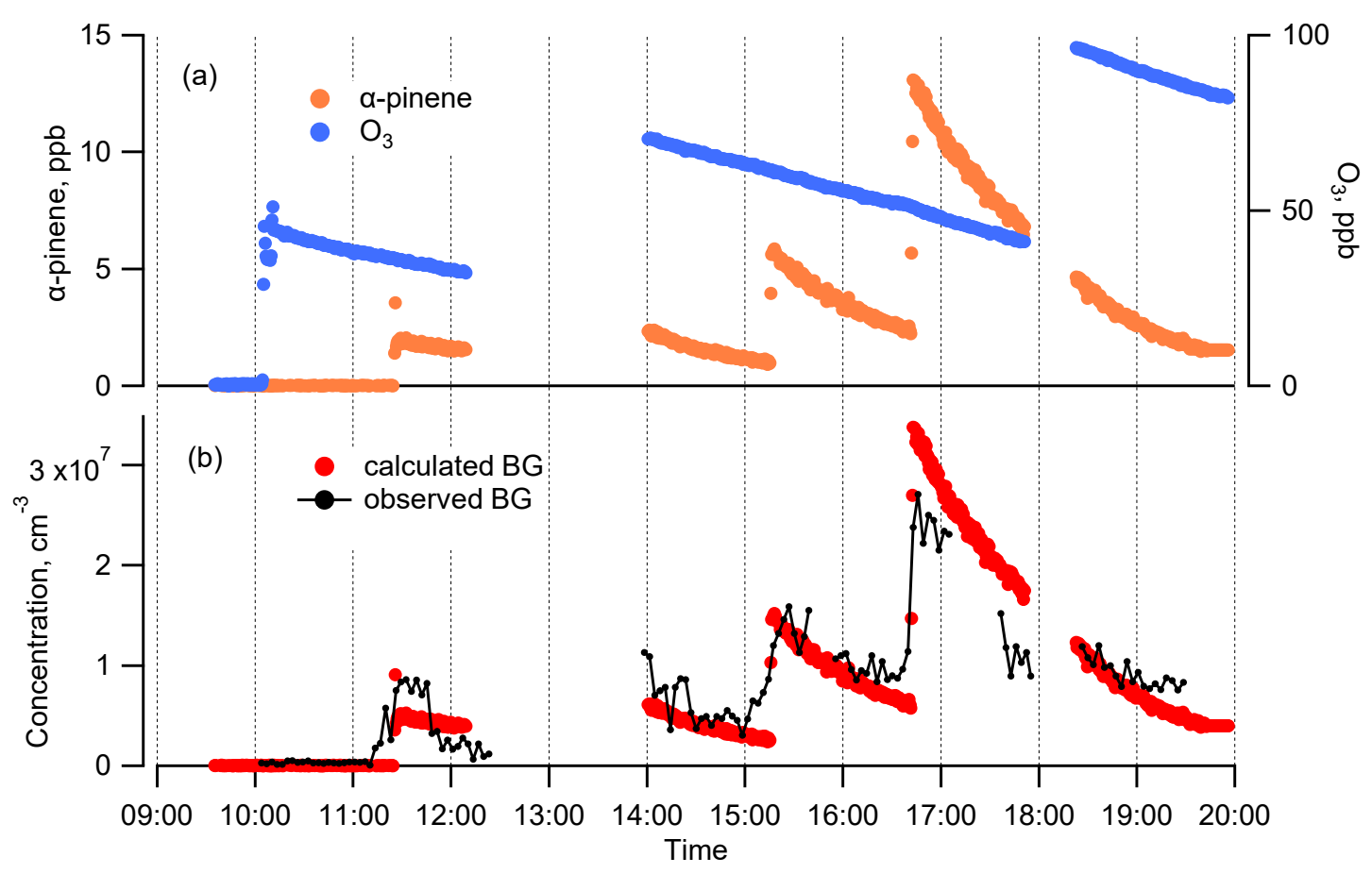

Figure S14. Example of a chamber study of the $\alpha$-pinene ozonolysis showing dependence of background level (BG) on the SCI production rate: (a) $\alpha$-pinene and ozone concentrations, (b) observed (black) and calculated (red) background levels. The calculations were made assuming $\mathrm{O}_{3}$ concentration of $2 \mathrm{ppm}$ in the IMR. 


\section{References}

Atkinson, R., Baulch, D. L., Cox, R. A., Crowley, J. N., Hampson, R. F., Hynes, R. G., Jenkin, M. E., Rossi, M. J. and Troe, J.: Evaluated kinetic and photochemical data for atmospheric chemistry: Volume I - gas phase reactions of $\mathrm{O}_{\mathrm{x}}, \mathrm{HO}_{\mathrm{x}}, \mathrm{NO}_{\mathrm{x}}$ and $\mathrm{SO}_{\mathrm{x}}$ species, Atmos. Chem. Phys., 4(6), 1461-1738, doi:10.5194/acp-4-14612004, 2004.

Atkinson, R., Baulch, D. L., Cox, R. A., Crowley, J. N., Hampson, R. F., Hynes, R. G., Jenkin, M. E., Rossi, M. J., Troe, J. and IUPAC Subcommittee: Evaluated kinetic and photochemical data for atmospheric chemistry: Volume II - gas phase reactions of organic species, Atmos. Chem. Phys., 6(11), 3625-4055, doi:10.5194/acp-63625-2006, 2006.

Avzianova, E. V. and Ariya, P. A.: Temperature-dependent kinetic study for ozonolysis of selected tropospheric alkenes, Int. J. Chem. Kinet., 34(12), 678-684, doi:10.1002/kin.10093, 2002.

Barber, V. P., Pandit, S., Green, A. M., Trongsiriwat, N., Walsh, P. J., Klippenstein, S. J. and Lester, M. I.: FourCarbon Criegee Intermediate from Isoprene Ozonolysis: Methyl Vinyl Ketone Oxide Synthesis, Infrared Spectrum, and OH Production, J. Am. Chem. Soc., 140(34), 10866-10880, doi:10.1021/jacs.8b06010, 2018.

Bardouki, H., Berresheim, H., Vrekoussis, M., Sciare, J., Kouvarakis, G., Oikonomou, K., Schneider, J. and Mihalopoulos, N.: Gaseous ( DMS , MSA, $\mathrm{SO}_{2}, \mathrm{H}_{2} \mathrm{SO}_{4}$ and DMSO ) and particulate ( sulfate and methanesulfonate ) sulfur species over the northeastern coast of Crete, Atmos. Chem. Phys., 3, 1871-1886, doi:10.5194/acp-3-1871-2003, 2003.

Berresheim, H., Elste, T., Tremmel, H. G., Allen, A. G., Hansson, H., Rosman, K., Maso, M. D., Mäkelä, J. M., Kulmala, M. and O'Dowd, C. D.: Gas-aerosol relationships of $\mathrm{H}_{2} \mathrm{SO}_{4}$, MSA, and $\mathrm{OH}$ : Observations in the coastal marine boundary layer at Mace Head, Ireland, J. Geophys. Res., 107, 1-12, doi:10.1029/2000JD000229, 2002.

Berresheim, H., Adam, M., Monahan, C., O’Dowd, C., Plane, J. M. C., Bohn, B. and Rohrer, F.: Missing $\mathrm{SO}_{2}$ oxidant in the coastal atmosphere? - Observations from high-resolution measurements of $\mathrm{OH}$ and atmospheric sulfur compounds, Atmos. Chem. Phys., 14(22), 12209-12223, doi:10.5194/acp-14-12209-2014, 2014.

Birmili, W., Wiedensohler, A., Plass-Dülmer, C. and Berresheim, H.: Evolution of Newly Formed Aerosol Particles in the Continental Boundary Layer : A Case Study Including $\mathrm{OH}$ and $\mathrm{H}_{2} \mathrm{SO}_{4}$ Measurements, Geophys. Res. Lett., 27(15), 2205-2208, 2000.

Black, G., Sharpless, R. L. and Slanger, T. G.: Rate coefficients at $298 \mathrm{~K}$ for $\mathrm{SO}$ reactions with $\mathrm{O}_{2}, \mathrm{O}_{3}$, and $\mathrm{NO}_{2}$, Chem. Phys. Lett., 90(1), 55-58, 1982.

Boy, M., Mogensen, D., Smolander, S., Zhou, L., Nieminen, T., Paasonen, P., Plass-Dülmer, C., Sipilä, M., Petäjä, T., Mauldin, L., Berresheim, H. and Kulmala, M.: Oxidation of $\mathrm{SO}_{2}$ by stabilized Criegee intermediate (sCI) radicals as a crucial source for atmospheric sulfuric acid concentrations, Atmos. Chem. Phys., 13(7), 38653879, doi:10.5194/acp-13-3865-2013, 2013.

Burkholder, J. B., Sander, S. P., Abbat, J., Barker, J. R., Huie, R. E., Kolb, C. E., Kurylo, M. J., Orkin, V. L., Wilmouth, D. M. and Wine, P. H.: Chemical Kinetics and Photochemical Data for Use in Atmospheric Studies, Evaluation No. 18, JPL Publication 15-10, Jet Propulsion Laboratory, Pasadena, [online] Available from: http://jpldataeval.jpl.nasa.gov/, 2015.

Caravan, R. L., Vansco, M. F., Au, K., Khan, M. A. H., Li, Y.-L., Winiberg, F. A. F., Zuraski, K., Lin, Y.-H., Chao, W., Trongsiriwat, N., Walsh, P. J., Osborn, D. L., Percival, C. J., Lin, J. J.-M., Shallcross, D. E., Sheps, L., Klippenstein, S. J., Taatjes, C. A. and Lester, M. I.: Direct kinetic measurements and theoretical predictions of an isoprene-derived Criegee intermediate, Proc. Natl. Acad. Sci., 117(18), 9733-9740, doi:10.1073/pnas.1916711117, 2020.

Creasey, D. J., Heard, D. E. and Lee, J. D.: Absorption cross-section measurements of water vapour and oxygen at $185 \mathrm{~nm}$. Implications for the calibration of field instruments to measure $\mathrm{OH}, \mathrm{HO}_{2}$ and $\mathrm{RO}_{2}$ radicals, , 27(11), $1651-1654,2000$.

Danielache, S. O., Eskebjerg, C., Johnson, M. S., Ueno, Y. and Yoshida, N.: High-precision spectroscopy of ${ }^{32}$ S , ${ }^{33} \mathrm{~S}$, and ${ }^{34} \mathrm{~S}$ sulfur dioxide : Ultraviolet absorption cross sections and isotope effects, J. Geophys. Res. Atmos., 113, D17314, doi:10.1029/2007JD009695, 2008.

Dusanter, S., Vimal, D. and Stevens, P. S.: Technical note : Measuring tropospheric $\mathrm{OH}$ and $\mathrm{HO}_{2}$ by laser- 
induced fluorescence at low pressure . A comparison of calibration techniques, Atmos. Chem. Phys., 8, 321-340, 2008.

Eisele, F. L. and Tanner, D. J.: Measurement of the gas phase concentration of $\mathrm{H}_{2} \mathrm{SO}_{4}$ and methane sulfonic acid and estimetes of $\mathrm{H}_{2} \mathrm{SO}_{4}$ production and loss in the atmosphere, J. Geophys. Res., 98, 9001-9010, 1993.

Grosjean, E., Grosjean, D. and Williams, E. L.: Rate constants for the gas-phase reactions of Ozone with unsaturated Alcohols, Esters and Carbonyls, Int. J. Chem. Kinet., 25, 783, doi:10.1002/kin.550261206, 1993.

IUPAC: Task Group on Atmospheric Chemical Kinetic Data Evaluation, http://iupac.pole-ether.fr, last access: April, 2020.

Jefferson, A., Tanner, D. J., Eisele, F. L. and Berresheim, H.: Sources and sinks of $\mathrm{H}_{2} \mathrm{SO}_{4}$ in the remote Antarctic marine boundary layer, J. Geophys. Res. Atmos., 103(D1), 1639-1645, doi:10.1029/97JD01212, 1998.

Kim, S., Guenther, A., Lefer, B., Flynn, J., Griffin, R., Rutter, A. P., Gong, L. and Cevik, B. K.: Potential role of stabilized Criegee radicals in sulfuric acid production in a high biogenic VOC environment, Environ. Sci. Technol., 49(6), 3383-3391, doi:10.1021/es505793t, 2015.

Kürten, A., Rondo, L., Ehrhart, S. and Curtius, J.: Calibration of a Chemical Ionization Mass Spectrometer for the Measurement of Gaseous Sulfuric Acid, J. Phys. Chem. A, 116, 6375-6386, 2012.

Lin, Y.-H., Yang, C., Takahashi, K. and Lin, J. J.-M.: Kinetics of Unimolecular Decay of Methyl Vinyl Ketone Oxide, an Isoprene-Derived Criegee Intermediate, under Atmospherically Relevant Conditions, J. Phys. Chem. A, 124, 9375-9381, doi:10.1021/acs.jpca.0c07928, 2020.

Lin, Y.-H., Yin, C., Takahashi, K., Lin, J.-M.; Surprisingly long lifetime of methacrolein oxide, an isoprene derived Criegee intermediate, under humid conditions, Commun. Chem., 4(12), https://doi.org/10.1038/s42004021-00451-z, 2021.

Mauldin III, R. L., Berndt, T., Sipilä, M., Paasonen, P., Petäjä, T., Kim, S., Kurtén, T., Stratmann, F., Kerminen, V.-M. and Kulmala, M.: A new atmospherically relevant oxidant of sulphur dioxide, Nature, 488(7410), 193196, doi:10.1038/nature11278, 2012.

Novelli, A., Vereecken, L., Lelieveld, J. and Harder, H.: Direct observation of $\mathrm{OH}$ formation from stabilised Criegee intermediates, Phys. Chem. Chem. Phys., 16(37), 19941-19951, doi:10.1039/C4CP02719A, 2014.

Novelli, A., Hens, K., Ernest, C. T., Martinez, M., Nölscher, A. C., Sinha, V., Paasonen, P., Petäjä, T., Sipilä, M., Elste, T., Plass-Dülmer, C., Phillips, G. J., Kubistin, D., Williams, J., Vereecken, L., Lelieveld, J. and Harder, H.: Estimating the atmospheric concentration of Criegee intermediates and their possible interference in a FAGE-LIF instrument, Atmos. Chem. Phys., 17(12), 7807-7826, doi:10.5194/acp-17-7807-2017, 2017.

Le Person, A., Eyglunent, G., Daële, V., Mellouki, A. and Mu, Y.: The near UV absorption cross-sections and the rate coefficients for the ozonolysis of a series of styrene-like compounds, J. Photochem. Photobiol. A Chem., 195(1), 54-63, doi:10.1016/j.jphotochem.2007.09.006, 2008.

Petäjä, T., Mauldin III, R. L., Kosciuch, E., McGrath, J., Nieminen, T., Paasonen, P., Boy, M., Adamov, A., Kotiaho, T. and Kulmala, M.: Sulfuric acid and $\mathrm{OH}$ concentrations in a boreal forest site, Atmos. Chem. Phys., 9, 7435-7448, 2009

Sander, S. P., Abbatt, J., Barker, J. R., Burkholder, J. B., Friedl, R. R., Golden, D. M., Huie, R. E., Kolb, C. E., Kurylo, M. J., Moortgat, G. K., Orkin, V. L. and Wine, P. H.: Chemical Kinetics and Photochemical Data for Use in Atmospheric Studies, Evaluation No. 17," JPL Publication 10-6, Jet Propulsion Laboratory, Pasadena, http://jpldataeval.jpl.nasa.gov, 2011.

Tennekes, H. and Lumley, J. L.: A first course in turbulence, Cambridge, Mass. : MIT Press., 1972.

Vereecken, L., Novelli, A. and Taraborrelli, D.: Unimolecular decay strongly limits the atmospheric impact of Criegee intermediates, Phys. Chem. Chem. Phys., 19, 31599-31612, doi:10.1039/C7CP05541B, 2017.

Weber, R. J., Marti, J. J., Mcmurry, P. H., Eisele, F. L., Tanner, D. J. and Jefferson, A.: Measurements of new particle formation and ultrafine particle growth rates at a clean continental site, J. Geophys. Res., 102, 43754385, 1997.

Whitehill, A. R., Jiang, B., Guo, H. and Ono, S.: $\mathrm{SO}_{2}$ photolysis as a source for sulfur mass-independent isotope signatures in stratospehric aerosols, Atmos. Chem. Phys., 15, 1843-1864, doi:10.5194/acp-15-1843-2015, 2015. 
Witter, M., Berndt, T., Böge, O., Stratmann, F. and Heintzenberg, J.: Gas-phase ozonolysis: Rate coefficients for a series of terpenes and rate coefficients and $\mathrm{OH}$ yields for 2-methyl 2-butene and 2,3-dimethyl-2-butene, Int. J. Chem. Kinet., 34(6), 394-403, doi:10.1002/kin.10063, 2002.

Zhang, D., Lei, W. and Zhang, R.: Mechanism of $\mathrm{OH}$ formation from ozonolysis of isoprene: Kinetics and product yields, Chem. Phys. Lett., 358(3-4), 171-179, doi:10.1016/S0009-2614(02)00260-9, 2002. 